\title{
AGE DIFFERENCES IN JOB DISPLACEMENT, JOB SEARCH, AND REEMPLOYMENT
}

\author{
Richard W. Johnson and Corina Mommaerts
}

CRR WP 2011-3

Date Released: January 2011

Date Submitted: December 2010

\author{
Center for Retirement Research at Boston College \\ Hovey House \\ 140 Commonwealth Avenue \\ Chestnut Hill, MA 02467 \\ Tel: 617-552-1762 Fax: 617-552-0191 \\ http://crr.bc.edu
}

Richard Johnson is a senior fellow at the Urban Institute. Corina Mommaerts is a research assistant at the Urban Institute. The research reported here was performed pursuant to a grant from the U.S. Social Security Administration (SSA) funded as part of the Retirement Research Consortium (RRC). The opinions and conclusion expressed are solely those of the authors and do not represent the opinions or policy of SSA, any agency of the federal government, the RRC, the Urban Institute, or Boston College.

(C) 2011, by Richard W. Johnson and Corina Mommaerts. All rights reserved. Short sections of text, not to exceed two paragraphs, may be quoted without explicit permission provided that full credit, including $(\odot$ notice, is given to the source. 


\title{
About the Center for Retirement Research
}

The Center for Retirement Research at Boston College, part of a consortium that includes parallel centers at the University of Michigan and the National Bureau of Economic Research, was established in 1998 through a grant from the Social Security Administration. The Center's mission is to produce first-class research and forge a strong link between the academic community and decision makers in the public and private sectors around an issue of critical importance to the nation's future. To achieve this mission, the Center sponsors a wide variety of research projects, transmits new findings to a broad audience, trains new scholars, and broadens access to valuable data sources.

\author{
Center for Retirement Research at Boston College \\ Hovey House \\ 140 Commonwealth Avenue \\ Chestnut Hill, MA 02467 \\ phone: 617-552-1762 fax: 617-552-0191 \\ e-mail: crr@bc.edu \\ crr.bc.edu
}

Affiliated Institutions:

The Brookings Institution

Massachusetts Institute of Technology

Syracuse University

Urban Institute 


\begin{abstract}
Working longer is often hailed as the best way to increase retirement incomes, yet this strategy depends crucially on seniors' ability to find work and hold on to their jobs. This study examines how the incidence and consequences of job displacement vary by age. Data come primarily from the 1996, 2001, and 2004 panels of the Survey of Income and Program Participation (SIPP), which follow respondents for up to 48 months. The data span the years 1996 to 2007, covering the 2001 recession but not the 2007-2009 recession.

Results show that older workers are less likely than younger workers to lose their jobs, but only because they generally have spent more time with their employers. When older workers lose their jobs, they appear to have more trouble than their younger counterparts finding work. Compared with their counterparts ages 25 to 34, displaced men ages 50 to 61 are 39 percent less likely to become reemployed each month and displaced women ages 50 to 61 are 18 percent less likely. When older displaced workers find jobs, they typically experience sharp wage declines. Among displaced men who become reemployed, for example, the median hourly wage on the new job falls 20 percent below the median wage on the old job at ages 50 to 61 , compared with only 2 percent at ages 25 to 34 . These findings suggest that some employers are reluctant to hire older workers, and raise questions about the employability of older adults.
\end{abstract}




\section{Introduction}

As the population ages, the employability of older adults is becoming increasingly important. Adults age 50 and older made up 31 percent of the labor force in 2010, up from 20 percent in 1995. If labor force participation rates at older ages continue to grow at their 1999 to 2009 pace, by 2019 adults age 50 and older will account for 35 percent of the labor force. ${ }^{2}$ Working longer is often hailed as the best way to increase retirement incomes (Munnell and Sass 2008), yet the strategy depends crucially on seniors' ability to find work and hold on to their jobs. Being out of work is especially serious for older workers who are too young to qualify for Social Security retirement benefits, which provides an important lifeline for nonworking adults age 62 and older (Johnson and Mermin 2009). Questions about the employability of older adults are particularly relevant in the wake of the Great Recession of 2007-09, when the demand for labor remains weak and unemployment rates are near record highs.

Job loss is an inevitable consequence of a dynamic economy. Employers must be able to shed jobs in response to changing market conditions, and their ability to do so at relatively low cost encourages them to hire more employees. Workers in declining industries often lose their jobs, but growing sectors provide new employment opportunities. Although job creation and destruction help distribute resources efficiently and promote economic growth, this dynamic process can impose significant costs on individual workers. Displaced workers forfeit wages, sometimes for extended periods, and the stress of being out of work takes financial, physical, and emotional tolls on the unemployed. The consequences of job loss may be especially serious for older workers, who may encounter more difficulty finding jobs than their younger counterparts.

This study uses recent longitudinal data from the Survey of Income and Program Participation (SIPP) to examine how the incidence and consequences of job loss vary by age. Models measure the likelihood that workers lose their jobs through no fault of their own and the likelihood that displaced workers become reemployed. We also compare earnings and other job characteristics before and after job loss for displaced workers who become reemployed. Final tabulations compare job search activities by age for unemployed workers. Results show that older workers are less likely than younger workers to lose their jobs, but only because they generally have spent more time with their employers. Older workers who become displaced

\footnotetext{
${ }^{1}$ These estimates are based on the authors' calculations from Bureau of Labor Statistics (2010b).

${ }^{2}$ This calculation assumes that age- and sex-specific participation rates for workers ages 16 to 49 continue at the average monthly rate that prevailed from January to October 2010.
} 
spend more time unemployed than their younger counterparts and experience greater wage losses when they become reemployed. These findings suggest that some employers are reluctant to hire older workers, and raise questions about the employability of older adults.

\section{Background}

An extensive literature documents the patterns and consequences of job loss. Several recent studies use the Current Population Survey (CPS) to compare unemployment rates across different population groups (Acs and Alsalam 2010; Michealides and Mueser 2009; Elsby, Hobijn, and Sahin 2010; Shierholz 2010). Unemployment is more common among men than women, among the young than the old, among African Americans and Hispanic than nonHispanic whites, and among workers with limited education than college graduates. These patterns have persisted for decades, although there is some evidence that the gender gap in unemployment has increased (Sahin, Song, and Hobijn 2010). Michaelides and Mueser (2009), however, find that unemployment is more prevalent among women than men (not less) after they control for gender differences in occupation and industry.

The unemployment rate measures the fraction of the labor force at a point in time that is not working and actively seeking work. A disadvantage of focusing on this measure is that it does not distinguish between the number of employed workers who become unemployed and the number of unemployed workers who become employed, both of which affect the number of workers who are unemployed. To disentangle these effects, several studies examine job loss among employed workers and reemployment rates among unemployed workers.

Much research on job loss and subsequent reemployment uses the Displaced Workers Survey (DWS), a supplement to the CPS that has been conducted every other year since 1984 (Farber 2005; Farber, Hall, and Pencavel 1993; Farber, Haltiwanger, and Abraham 1997; Gibbons and Katz 1991; Hu and Taber 2005; Munnell et al. 2006; Neal 1995; Podgursky and Swaim 1987; Rodriguez and Zavodny 2003). The DWS asks workers whether they have lost their jobs over the past three years. The survey captures only those worker terminations that result from employer business decisions that are unrelated to the worker's performance, such as job losses that result when a plant or company closes or moves, there is insufficient work, or a position or shift is abolished. Terminations for cause are not included. 
Job loss patterns are similar to unemployment rate patterns. For example, job displacement increases during periods of high unemployment, and job loss rates are higher among workers with limited education than among their better-educated counterparts (Farber 2005; Munnell et al. 2006; Rodriguez and Zavodny 2003). However, the cyclical pattern of job loss is weaker for workers with more than a high school education, whose displacement rates do not increase as much during economic slowdowns as those for less-educated workers. Moreover, job loss has been increasing for well-educated workers, but not for those with no more than a high school diploma (Farber 2005; Munnell et al. 2006). Job loss is also more common among working men than working women, those employed in manufacturing than services, and those with shorter job tenures (Munnell et al. 2006; Rodriguez and Zavodny 2003).

Education appears to increase the likelihood of becoming reemployed after a layoff (Farber 2005; Munnell et al. 2006). Post-displacement employment rates are also higher among men than women. The availability and generosity of unemployment benefits increases unemployment spells, although temporary benefit extensions have smaller effects (Card and Levine 2000; Katz and Meyer 1990; Lalive, van Ours, and Zweimuller 2006; Moffitt 1985; Mortensen 1977; Schwartz 2010).

Displaced workers who become reemployed generally earn less on the post-displacement job than the previous job, and the effects are often long-lasting. Using data from the DWS, Farber (2005) reports that average weekly earnings for full-time workers who lost their jobs between 2001 and 2003 and returned to full-time work were 14 percent lower on their postdisplacement job than their previous job. The average weekly earnings loss increases to 17 percent when the comparisons account for earnings growth that displaced workers would have experienced had they remained employed. Studies based on longitudinal household survey data show similar declines. Using Panel Survey of Income Dynamics (PSID) data, Stevens (1997) finds that earnings decline 25 percent in the first year after displacement and then recover somewhat, but earnings six years after the first observed job loss remain 9 percent lower for displaced workers than for otherwise identical workers who never lost their jobs. Ruhm (1991), who also examines PSID data, finds that earnings initially fall 16 percent and remain low indefinitely. Earnings losses tend to be larger among displaced workers with more job tenure and among those who change industries when they become reemployed (Carrington 1993; Farber 2005). 
Several studies examine how job displacement affects future earnings by using administrative data, which often extend further than survey data and allow researchers to measure longer-term effects. For example, Jacobson, LaLonde, and Sullivan (1993) and Couch and Placzek (2010) use records on individual earnings and firm-level employment from state unemployment insurance systems to identify workers with employment breaks. They define displaced workers as those who separated from their employers during a "mass layoff," when the firm's employment level falls below 30 percent of the pre-layoff high. Most workers who separate when the firm experiences a mass layoff likely leave involuntarily, through no fault of their own. Results from these studies show large and persistent earnings losses associated with job displacement. Earnings losses among workers displaced in Pennsylvania in the early 1980s averaged 40 percent in the first year, and remained as high as 25 percent six years later (Jacobson, LaLonde, and Sullivan 1993). Job displacement reduced earnings less in Connecticut in the 1990s and early 2000s, when the economy was stronger than in the early 1980s, but the impact was still substantial. Initial earnings losses among displaced workers in Connecticut averaged about 30 percent, and were as much as 15 percent six years later (Couch and Placzek 2010). Other research based on California unemployment insurance records and national Social Security earnings records also finds that job loss substantially reduces subsequent earnings, and that the effects are long-lasting (von Wachter and Handwerker 2009; von Wachter, Song, and Manchester 2009).

In addition to having serious financial consequences, unemployment spells appear to complicate health problems and family relations. Job loss tends to disrupt marriages (Charles and Stephens 2004), increase smoking and drinking (Falba et al. 2005; Gallo et al. 2001), promote depression (Brand, Levy, and Gallo 2008), impair physical health, (Browning, Dano, and Heinesen 2006; Gallo et al. 2006), and even increase mortality (Eliason and Storrie 2007; Sullivan and von Wachter 2009). ${ }^{3}$ These effects likely stem from the loss of income and health insurance coverage that often accompany unemployment, as well as the increased stress that usually results from job loss.

\footnotetext{
${ }^{3}$ Salm (2009), however, concludes that job loss is associated with poor health outcomes because workers with health problems are more likely to lose their jobs than healthy workers, not because job loss causes health problems.
} 


\section{Effects of Job Displacement on Older Workers}

By most measures, older adults fare well in the labor market. Workers age 50 and older generally earn more than younger workers, they are more likely to participate in retirement and health plans on the job, and they are less likely to find themselves unemployed. ${ }^{4}$ Several studies confirm that older workers are less likely to lose their jobs than younger workers, although there is some evidence that older workers' advantage may be eroding (Farber 2005; Munnell et al. 2006; Rodriguez and Zavodny 2003).

When older workers lose their jobs, however, it seems to take them longer to become reemployed than their younger counterparts. For example, unemployed adults ages 55 to 64 averaged 29 weeks looking for work in 2009, compared with 23 weeks for those ages 25 to 34 (Bureau of Labor Statistics 2010c). In March 2010, the John J. Heldrich Center for Workforce Development resurveyed a nationally representative sample of Americans who reported being unemployed in an August 2009 survey. Only 14 percent of those age 55 and older were employed in March 2010, compared with 37 percent of those younger than 55 (Heidkamp, Corre, and Van Horn 2010). About a fifth (21 percent) of the older workers were still unemployed and had stopped looking for work, primarily because they had become discouraged by their poor job prospects. Earlier studies find that only 61 percent of displaced men and 55 percent of displaced women in their fifties are employed two years after a job loss (Chan and Stevens 2001), and that only about half of displaced workers in their early 60s become reemployed (Munnell et al. 2006). Another study reports that only about half of older job searchers find work (Maestas and $\mathrm{Li}$ 2006).

There is also evidence that older displaced workers suffer large earnings losses when they become reemployed. Using Health and Retirement Study data on displaced workers age 50 and older, Chan and Stevens (2001) report that job loss reduces earnings by 32 percent in the year following displacement, and that earnings remain between 23 and 29 percent lower six years later. Couch, Jolly, and Placzek (2009), using administrative earnings data from Connecticut

\footnotetext{
${ }^{4}$ In 2009, median usual weekly earnings among full-time wage and salary workers was $\$ 841$ at ages 55 to 64 , compared with $\$ 817$ at ages 35 to 44 and $\$ 678$ at ages 25 to 34 (Bureau of Labor Statistics 2010a). Among full-time workers at 55 to 61,61 percent participate in a retirement plan on the job (according to our estimates from 2009 SIPP data) and 83 percent receive employer-sponsored health insurance benefits (according to our estimates from 2008 American Community Survey data). Among full-workers ages 25 to 34, by contrast, only 50 percent participate in a retirement plan and 70 percent receive employer-sponsored health insurance benefits. The October 2010 unemployment rate was 6.6 percent at ages 55 to 64, compared with 7.9 percent at ages 35 to 44 and 9.9 percent at ages 25 to 34 (Bureau of Labor Statistics 2010b).
} 
unemployment insurance records, find that earnings losses following displacement increase with age. Their results show that in the first year after displacement, earnings losses average 20 percent at age 40, 26 percent at age 50, and 59 percent at age 62 .

\section{Data and Methods}

This study builds on the displaced worker literature by using longitudinal household data from the 1996, 2001, and 2004 SIPP panels to compare job loss and reemployment for older and younger workers. The SIPP is a nationally representative longitudinal household survey conducted by the U.S. Census Bureau that collects data on employment, job characteristics, income, assets, program participation, health status, demographics, and other topics. Households are surveyed every four months, but SIPP collects information from respondents on many topics, including employment and income, for each of the intervening three months, as well as the survey month. The 1996 and 2004 panels consist of 12 waves (spanning four years), and the 2001 panel consists of nine waves spread over three years. We pool the 1996, 2001, and 2004 panels to maximize the number of respondents with job losses that we can observe. ${ }^{5}$ Our data, then, span the years 1996 to 2007, covering the 2001 recession but not the 2007-2009 recession. ${ }^{6}$ All financial amounts are expressed in constant 2009 dollars. We construct different samples for our job displacement analysis, reemployment analysis, and job comparisons before and after layoffs.

Although the SIPP has not been used in many previous studies of displaced workers, it provides a number of advantages over other commonly used data sources. Because it follows respondents over time and interviews them every four months, reported job loss in the SIPP is less subject to recall bias than in the DWS, which asks respondents to report job loss over the past three years and collects information on only one episode of job displacement during that period. Moreover, the DWS does not gather information on time-varying personal or job characteristics at the time respondents lose their jobs, making it difficult to measure the impact of variables such as health status on displacement. A drawback of administrative datasets is that job separations observed in those samples will include some voluntary quits, even during periods of mass layoffs, because unlike the SIPP administrative data do not generally include information

\footnotetext{
${ }^{5}$ We do not use earlier panels because they lack reliable information on why respondents separate from their jobs.

${ }^{6}$ Some 1996 panel respondents were first interviewed in December 1995.
} 
about why workers left their employers. Also, administrative datasets do not usually include information of work hours, so observed earnings differences on pre- and post-displacement jobs will reflects changes in the hourly wage as well as changes in work hours. This may be particularly problematic for older workers, many of whom substantially reduce their hours when they change jobs (Johnson, Kawachi, and Lewis 2009).

\section{Job Loss}

Our sample for examining job loss consists of person-month observations on wage and salary workers age 18 and older. Because an underlying motivation for our study is to understand better how employers treat older workers, we exclude self-employed workers. Respondents enter the sample when we first observe them employed and remain in the sample until they separate from their original employer, they drop out of the survey, or the survey ends. We include in the sample only the first observed job spell for each worker. We classify respondents as displaced workers if they report separating from their employer because of layoff, slack work, or employer bankruptcy, or because the employer sold the business. Observations on workers who remain with the original employer when last interviewed or who leave the employer for reasons other than displacement (such as voluntary quits) are treated as censored. The sample includes 72,155 male workers and 72,479 female workers.

We compare the cumulative probability of job displacement for employed men and women ages 18 to 24,25 to 34,35 to 49,50 to 61 , and 62 or older, beginning when we first observe them at work. The age threshold for the oldest group is set to coincide with Social Security's early entitlement age.

We then estimate logit models of the log odds of job displacement. Because the data are arranged in person-wave format and respondents remain in the sample only when at risk of losing their jobs, the results can be interpreted as discrete-time hazard models of job displacement (Allison 1984). The advantage of these models is that they readily accommodate time-varying predictors. We estimate separate models for men and women. The sample includes $1,743,700$ person-month observations for men and 1,702,822 person-month observations for women.

The simplest specification controls only for age (indicators for ages 18 to 24,35 to 49,50 to 61, and 62 or older, relative to workers 25 to 34) and year (indicators for 2001 to 2003 and 
2004 to 2007 , relative to 1996 to 2000). We then incrementally add demographic and job characteristics to the model to measure how these controls change the estimated impact of age on job loss hazards. Demographic controls include indicators for race and ethnicity, education, marital status, region of the United States, and fair or poor health (relative to excellent, very good, or good health). ${ }^{7}$ Job characteristic measures include indicators for employer size (measured in broad categories as the number of workers employed at all of the employer's locations), part-time employment (measured as working fewer than 35 hours in a usual week), membership in a union or similar employee association, broad occupation, broad industry, and months of service with the current employer. The final specification adds interactions between age and year indicators, to measure whether the impact of age on job displacement changed over the 1996 to 2007 period.

\section{Reemployment}

The next stage of the study examines reemployment probabilities for displaced workers. Our sample consists of person-month observations on adults age 18 and older whom we observe becoming displaced from a wage and salary job. Respondents enter the sample when we first observe them losing their job and remain in the sample until they become reemployed, they drop out of the labor force, they drop out of the survey, or the survey ends. The sample includes 3,567 displaced men and 3,042 displaced women.

We graph the cumulative probability of becoming reemployed for different age groups and then estimate logit models of the log odds of becoming reemployed. These hazard models, estimated separately for men and women, control for age, year, demographics, characteristics of the former job, economic status of the household, receipt of unemployment insurance benefits, and number of months unemployed. Demographic and economic controls include race and ethnicity, education, marital status, an indicator for being married to a spouse who is employed, region of the United States, fair or poor health status, the natural log of monthly household income, and the natural log of monthly household wealth (including an indicator for negative household wealth). Characteristics of the previous job include the natural log of earnings in the last full month employed, employer size (measured as the number of employees at all locations),

\footnotetext{
${ }^{7}$ Information on health status is collected in several topical SIPP modules, so it is not available every month. We use health status from the wave closest to the observation month.
} 
part-time employment, union membership, occupation, industry, and job tenure (in months) at the end of the last job. Our initial specification includes only age dummies. As with the job loss hazards, we then incrementally add controls to the equations to examine how they change the estimated impact of age. The sample includes 11,231 person-month observations for men and 9,517 person-month observations for women.

\section{Job Comparisons}

We examine several aspects of the pre-displacement job and post-displacement job for displaced workers who become reemployed, and compare changes by age. The sample includes 2,641 reemployed men and 2,093 reemployed women. We compute the percentage of reemployed men and women who move into different occupations and industries on the new job, and the percentage who become self-employed. We also compare mean hours, the median hourly wage, and median monthly earnings on the new and old jobs.

We then estimate ordinary least squares (OLS) regressions of the difference in the hourly wage between the old and new jobs for reemployed men and women. Regressors include indicators for age, demographics (race and ethnicity, education, marital status, region of United States), employment of the spouse, the natural log of household wealth, union membership, selfemployment, and year, all measured at the start of the new job. Additional specifications include measures of health status, employer size, part-time status, occupation, and industry at the end of the old job and the beginning of the new job.

\section{Job Search}

The final stage of our analysis examines job search activities by unemployed workers. Data come from the CPS, a nationally representative monthly household survey conducted by the U.S. Census Bureau for the Bureau of Labor Statistics. The survey asks unemployed respondents whether they have engaged in any of a wide array of search activities over the past four weeks, including contacting employers, public employment agencies, private employment agencies, or friends and relatives. We compare responses by age, sex, and education. To maximize sample size, we pool observations from the March, April, May, and June 2010 surveys, a period of unusually high unemployment. The resulting sample includes observations on 17,750 unemployed workers. 


\section{Results}

We first report our findings on the incidence of job displacement, show how it varies by age, and identify its correlates. We then turn to the consequences of job displacement, presenting reemployment rates for younger and older displaced workers, describing the factors related to reemployment, and comparing the new jobs obtained by reemployed displaced workers to their former positions. The final section shows how job search activities vary by age.

\section{Job Displacement Results}

For male wage and salary workers, the probability of becoming displaced from one's job generally declines with age. Over a twelve-month period, employed men ages 18 to 24 are 49 percent more likely to lose their jobs through no fault of their own than those ages 35 to 49 (5.8 vs. 3.9 percent) and 66 percent more likely than those ages 50 to 61 (3.5 percent of whom become displaced) (figure 1). Age differences become less pronounced as the observation period lengthens, but are still substantial. After 36 months, for example, employed men ages 18 to 24 are 31 percent more likely to become displaced from their jobs than their counterparts ages 50 to 61.

Age differences in job displacement among men are less dramatic after age 25, although employment is somewhat more secure for men age 50 and older. Compared with men ages 25 to 34, men ages 50 to 61 are 15 percent less likely to lose their jobs over a 12-month period (4.1 vs. 3.5 percent) and 11 percent less likely over a 36-month period (7.5 vs. 6.7 percent).

Displacement rates are similar for men ages 50 to 61 and those age 62 and older. Compared again with men ages 25 to 34 , those age 62 or older are 17 percent less likely to lose their jobs over a 12-month period (4.1 vs. 3.4 percent) and 16 percent less likely over a 36-month period (7.5 vs. 6.3 percent).

Age patterns in displacement rates are not as well defined for women. Overall, employed women are only about five-sixths as likely to lose their jobs as employed men. Between 1996 and 2007, only 6.4 percent of female wage and salary workers are displaced from their jobs over a 36-month period, compared with 7.5 percent of men. The likelihood that women become displaced in a 12-month period generally declines with age (but not dramatically) (figure 2). Employed women ages 50 to 61 are 24 percent less likely than those ages 25 to 34 to lose their 
jobs over 12 months ( 3.8 vs. 2.9 percent), and those age 62 or older are 21 percent less likely (3.8 vs. 3.0 percent). The age pattern becomes more complex when we consider longer follow-up periods, however. After 36 months, for example, workers ages 35 to 49 and age 62 or older are about as likely to have lost their jobs (both 6.4 percent) as those ages 18 to 24 (6.3 percent), and those ages 25 to 34 are the most likely to have lost their jobs (6.7 percent). Displacement rates remain low throughout for female workers ages 50 to 61, however. After 36 months, they are 13 percent less likely to lose their jobs than those ages 25 to 34 (6.7 vs. 5.8 percent).

To understand better what drives these age patterns, we estimate discrete-time hazard models of job displacement. Table 1 describes the sample. Overall, we observe 16.7 percent of the wage and salary workers in the sample separating from their employers. Most of these separations are "voluntary"; only 26.9 percent result from job layoffs or slack work or follow the sale or bankruptcy of the employer's business. Displacements as a share of all separations were highest at ages 35 to 49 (when they peak at 36.5 percent) and are lowest at the ends of the age spectrum. As a share of all job separations, displacements fall to 16.1 percent for those ages 18 to 24 (who exhibit high quit rates as they sample different jobs before settling into long-term employment) and 20.2 percent for those age 62 or older (many of whom choose to retire).

The most substantial difference between older and younger workers is average job tenure. At baseline, mean job tenure is 133.6 months (or 11.1 years) for workers ages 50 to 61 and 128.5 months (10.7 years) for workers age 62 or older, compared with 37.1 months (3.1 years) for workers ages 25 to 34 and 85.5 months (7.1 years) for workers ages 35 to 49 . Workers age 62 or older tend to be in worse health and have less education than younger workers. More than onesixth of workers in the oldest age group, many of whom were born before 1934, did not complete high school. Workers ages 50 to 61 , however, are just as well educated as younger workers, although their health status is generally somewhat worse than that for younger workers. Additionally, workers older than 61 or younger than 25 are more likely than those of other ages to work for employers with fewer than 25 employees or to work part-time.

Table 2 reports results of our job displacement hazard models for male wage and salary workers. When controlling only for age and year (column 1), the model shows that displacement hazards fall sharply with age. Men ages 50 to 61 are 21 percent less likely than those ages 25 to 
34 to be displaced from their jobs, and men age 62 or older are 23 percent less likely. ${ }^{8}$ Controlling for demographic and most job characteristics reduces the estimated job loss advantage somewhat for workers in their 50s and increases it somewhat for workers age 62 or older. When we add demographics, health status, monthly earnings, employer size, part-time employment, union membership, occupation, and industry to the specification (column 3), we find that workers ages 50 to 61 are only 11 percent less likely than those ages 25 to 34 to become displaced, whereas those age 62 or older are 30 percent less likely to lose their jobs.

Adding job tenure to the specification (column 4), however, transforms the estimated impact of age. Each additional year of service with the employer reduces the monthly job displacement hazard by about 5 percent. When we control for job tenure along with demographics and other job characteristics, we find that men ages 50 to 61 are 24 percent more likely than those ages 25 to 34 to lose their jobs. The turning point occurs at about 4.6 years of service. Our results indicate that a worker in his 50s with less than 4.6 years of job tenure is more likely to become displaced than an otherwise identical newly hired worker in his late 20 s or early 30s; a 55-year-old worker with more than 4.6 years of job tenure is less likely to lose his job than the younger new hire. Controlling for length of service with the employer eliminates any significant job displacement differences between workers age 62 or older and those ages 25 to 34.

Job displacements are significantly higher in 2001 to 2003, when the economy was in recession and then recovering, than in 1996 to 2000, when the economy was strong. When we interact age with year in our model (column 5), we find that being ages 50 to 61 more strongly increases job displacement hazards in the 2001 to 2003 period than in 1996 to 2000. The interaction term of ages 50 to 61 and year 2004 to 2007 is positive but not quite significant. It is unclear whether the effect in the early 2000s for older workers not yet eligible for Social Security marks the beginning of a longer-term trend of heightened labor market challenges for older workers, is related to the weak labor market that prevailed at that time, or is simply an anomaly. Other age-year interactions in the model are insignificant.

Many job and demographic characteristics besides age significantly influence job displacement. For example, the likelihood of job loss falls as educational attainment and monthly

\footnotetext{
${ }^{8}$ These relative effects are derived by dividing the estimated marginal effect ( 0.049 in the case of workers ages 50 to 61 ) by the mean of the dependent variable $(0.231)$.
} 
earnings increase. When we control only for demographic characteristics, college graduates are 43 percent less likely than those with only a high school diploma to be displaced from their job. When we control for service with the employer and other job characteristics, college graduates' advantage falls to 18 percent (but remains highly statistically significant). African Americans are 10 percent more likely to lose their jobs than non-Hispanic whites when we control for job tenure and other characteristics. Married workers are generally less likely than others to become displaced, whereas those in fair or poor health are generally more likely to lose their jobs. Workers in the Northeast and West are significantly more likely to lose their jobs than those in the South and Midwest. Part-time work and employment with a small employer increase job displacement risks. Union members are less likely than others to lose their jobs, but the effect disappears when we control for job tenure.

Table 3 shows results for women from our job displacement hazard models. The findings are similar to those for men: older workers are significantly less likely than younger workers to lose their jobs, but the effect disappears when we account for length of service with the employer. Controlling for only age and year (column 1), the model shows that female wage and salary workers ages 50 to 61 are 30 percent less likely to lose their jobs than those ages 25 to 34 , and workers age 62 or older are 13 percent less likely to lose their jobs. The difference between the two older age groups disappears when we control for demographic and job characteristics except tenure. In that specification (column 3), workers ages 50 to 61 are 21 percent less likely to be displaced than those ages 25 to 34, compared with 23 percent for workers age 62 or older. When we control for job tenure (column 4), there is no significant difference in job displacement among workers ages 25 to 34,35 to 49,50 to 61 , and 62 or older. (Workers ages 18 to 24 are significantly less likely to lose their jobs than older workers when we control for demographics and job characteristics, including length of service with the employer). As with men, women are more likely to loss their jobs in 2001 to 2003 than in 1996 to 2000, but the impact of age on job displacement does not vary significantly over time.

The impact of job and demographic factors other than age on women's job displacement is similar to what we find for men. Job loss is more common among African American women, women with limited education and earnings, and those in fair or poor health than other women. For example, women who did not complete high school are about 30 percent more likely to be displaced from their jobs than high school graduates. Among women, unlike men, Hispanics are 
significantly more likely to lose their jobs than non-Hispanic whites. Controlling for demographic and job characteristics including tenure, Hispanics are 10 percent more likely than non-Hispanic whites to lose their jobs, whereas African Americans are 25 percent more likely. Working part-time and working for a small employer also increase women's job loss risks. Female union members are less likely to lose their jobs than nonmembers, even after we control for job tenure.

\section{Reemployment Results}

Although displacement rates are lower for older workers than younger workers, older workers who lose their jobs spend more time unemployed than their younger counterparts. Figure 3 plots the reemployment hazard by age for men and women combined. (Because our sample of displaced workers is substantially smaller than our full sample of workers, we do not show reemployment rates separately for men and women.) Within six months of job loss, 76 percent of displaced workers ages 18 to 24,70 percent of those ages 25 to 34 , and 69 percent of those ages 35 to 49 become reemployed. By contrast, only 58 percent of displaced workers ages 50 to 61 and 48 percent of those age 62 or older find new jobs over the same period. The patterns are similar 12 months after job loss: 87 percent of displaced workers ages 35 to 49 and 92 percent of those ages 18 to 24 become reemployed, compared with only 79 percent of displaced workers ages 50 to 61 and 63 percent of those age 62 or older.

Table 4 describes the sample we use to estimate our hazard models of reemployment. As we see in the sample of workers at risk of displacement, workers age 62 or older looking for reemployment tend to be less well educated and in worse health than younger job seekers. They are also less likely to have an employed spouse and more likely to have worked part-time on their previous job than their counterparts ages 25 to 61 . Mean monthly earnings at the end of the previous job are highest among those ages 50 to 61 . Workers age 50 and older hold much more household wealth than their younger counterparts. They have also spent much more time with their previous employer. About one-fifth of displaced workers ages 25 to 61 receive unemployment insurance benefits in the first month after losing their job. Benefit receipt is less common among displaced workers older than 61 and especially among those younger than 25 .

Table 5 shows results from our reemployment hazard models for displaced male wage and salary workers. Older displaced workers are much less likely to find new employment than 
their younger counterparts. When the specification controls only for age (column 1), we find that displaced male workers ages 50 to 61 are 43 percent less likely each month to become reemployed than those ages 25 to 34 , and displaced male workers age 62 or older are 53 percent less likely. Adding other controls to the model does not affect these estimates much. When we hold other factors constant, such as other demographic characteristics, health status, economic factors, unemployment insurance receipt, time since job loss, and characteristics of the previous job (column 4), we find that men ages 50 to 61 are 39 percent less likely to find new work than those ages 25 to 34 , and those age 62 or older are 51 percent less likely.

Recall that our sample excludes displaced workers once they stop looking for work and drop out of the labor force. The disadvantage experienced by older workers, especially those age 62 or older, in finding new employment appears much larger when we expand our sample to include labor force dropouts. (These results are available from the authors upon request.)

Other factors also significantly reduce displaced men's chances of finding new employment. Race, unemployment insurance benefit receipt, and health status appear to play large roles. African Americans are 32 percent less likely each month and Hispanics 25 percent less likely each month to find new work than non-Hispanic whites. Displaced workers receiving unemployment benefits are 38 percent less likely to become reemployed than otherwise identical workers who are not receiving benefits. Reemployment rates are 21 percent lower for those in fair or poor health than for their healthier counterparts. The long-term jobless face special difficulties in the labor market. Each month that displaced workers spend unemployed reduces their employment chances by 6 percent. Education, economic status, and the characteristics of the previous job do not appear to affect reemployment chances much.

Table 6 shows reemployment hazard model results for displaced female wage and salary workers. The findings are similar to those for men. When we do not control for any other factors (column 1), we find that displaced women ages 50 to 61 are 23 percent less likely each month than those ages 25 to 34 to find new employment, and displaced women age 62 or older are 59 percent less likely. The estimated effects diminish only slightly when we control for other factors (column 4), falling to 18 percent for workers ages 50 to 61 and 50 percent for workers age 62 or older.

As we saw in the results for displaced men, African Americans, Hispanics, those with health problems, and those receiving unemployment insurance benefits are much less likely to 
become reemployed than other displaced workers. Monthly reemployment rates are 32 percent lower for African American women and 26 percent lower for Hispanic women than for nonHispanic white women. Women receiving unemployment benefits are 43 percent less likely to become reemployed than nonrecipients. And reemployment rates diminish the longer women have been unemployed. Displaced female union members, unlike their male counterparts, are more likely to find new jobs than nonmembers, and unmarried women are more likely to become reemployed than married women. As with men, women's education and economic status do not have much impact on reemployment rates.

\section{Comparisons of Old and New Jobs}

We now compare selected characteristics of the old and new job for displaced workers who become reemployed. Overall about half of displaced workers in our sample (51 percent of men and 52 percent of women) move into new occupations, broadly defined, when they become reemployed. Similarly, 53 percent of reemployed men and 47 percent of reemployed women move into new industries, broadly defined. Occupational and industry mobility does not vary much by age among displaced men ages 25 or older (table 7). Reemployed men ages 18 to 24 are significantly more likely than older men to change occupation or industry, however. Among displaced women, those age 62 or older are significantly less likely than those ages 25 to 34 to change occupation or industry after becoming reemployed, but there is not much difference in occupational or industry mobility between women ages 50 to 61 and younger women.

Although many wage and salary workers transition into self-employment at older ages (Karoly and Zissimopoulos 2004), it is not very common following layoffs. Overall, 4.4 percent of men and 3.2 percent of women who find work after being displaced from a wage and salary job move to self-employment. The share of displaced men transitioning into self-employment peaks at ages 50 to 61 , but the rate reaches only 6.0 percent (table 8). No displaced men age 62 or older in our small sample work for themselves when they became reemployed. Among reemployed displaced women, only 3.6 percent of those ages 50 to 61 and 1.0 percent of those age 62 or older become self-employed.

When displaced workers become reemployed, the hours they work on their new jobs does not differ much from the hours they worked before being laid off. Hours fall slightly on the new job among those who worked full-time (35 or more hours) on the old job, and increase somewhat 
more among those who worked part-time on the old job (table 9). However, the differences are modest, even among older workers. Reemployed workers age 62 or older who were employed full-time on their old jobs average only 1.1 fewer hours per week on the post-displacement job than the pre-displacement job.

When older displaced workers find new jobs, they generally earn substantially less than they did on their former job. Median hourly wages for reemployed men are 20.1 percent lower on the new job than the old job for men ages 50 to 61 and 35.6 percent lower on the new job for men age 62 or older (table 10). Younger displaced men fare much better when they find new employment. Compared to what they earned on the former job, median hourly earnings are only 4.2 percent lower for men ages 35 to 49 and 1.5 percent lower for men ages 25 to 34 .

Interestingly, the median hourly wage on the new job is lower for reemployed men ages 50 to 61 than for those ages 35 to 49. It is also lower at age 62 or older than for any of our groups older than 24. Displaced men ages 18 to 24 who become reemployed earn slightly more per hour on the new job than the old job.

Older displaced women also generally earn less on the new job when they become reemployed than they did on the old job, but wage losses after age 24 vary less by age for women than men. Median hourly earnings are 21.1 percent less on the new job than old job for women ages 50 to 61 and 15.6 percent less for women age 62 or older. However, wage losses are also steep for younger women, with median wages falling 18.3 percent at ages 25 to 34 and 10.2 percent at ages 35 to 49 . Median wages are 6.8 percent higher on the new job than old job for reemployed women ages 18 to 24 , however.

Table 11 compares median monthly earnings on the new and old jobs for displaced workers who become reemployed. As with hourly wages, monthly earnings losses are much more severe for older men than for their younger counterparts. Median monthly earnings are 20.6 percent lower on the new job than the old job for reemployed men ages 50 to 61 , and 30.0 percent lower for reemployed men age 62 or older. By contrast, median monthly earnings are only 8.0 percent lower on the new job than old job for men ages 35 to 49 and only 3.0 percent lower for men ages 25 to 34. For reemployed displaced women, median monthly earnings are substantially lower on the new job for all age groups older than 24 , but women ages 50 or older do not fare worse than women in their 30s and 40s. Median monthly earnings are 17.2 percent 
lower on the new job for women ages 50 to 61, compared with 15.8 percent lower for women ages 35 to 49 and 27.1 percent lower for women ages 25 to 34 .

Table 12 reports OLS regressions of the change in hourly earnings for displaced male workers who become reemployed. Controlling for demographics, health status, job characteristics, and economic status, we find that hourly wage losses on the new job compared to the pre-displacement job are nearly four times as large for men ages 50 to 61 as men ages 25 to 34 , and six times as large for men age 62 or older. ${ }^{9}$ Wage losses increase with education and with length of service with the pre-displacement employer. Wage losses are also especially high among those who move from full-time to part-time employment.

Wage losses among displaced reemployed women do not vary significantly with age for women older than 24 (table 13). Displaced women ages 18 to 24 who become reemployed experience much larger wage gains than older women. Women ages 50 to 61 and those age 62 or older do not experience significantly larger losses than women in their 30s or 40s, however.

\section{Job Search Activities}

Table 14 reports different job search activities pursued by unemployed workers over four-week periods in March, April, May, and June 2010. CPS data are available on nine different activities: (1) contacting employers directly, going for interviews, sending resumes, or completing job applications; (2) contacting public employment agencies; (3) contacting private employment agencies; (4) contacting school employment centers; (5) checking professional or union registers; (6) contacting family or friends about job openings; (7) placing or answering ads; (8) looking at ads; and (9) attending job training. When we include a catch-all "other" category, job searchers may engage in as many as 10 different activities. On average, however, job searchers pursued only 1.9 activities in any given month. About three-quarters of unemployed workers (77.1 percent) contacted employers directly or sent resumes or applications. The next most common activity was looking at ads (29.2 percent), followed by contacting friends and family (27.8 percent), contacting public employment agencies (19.6 percent) and placing or answering ads (16.3 percent). Few job searchers contacted private employment agencies, checked professional or union registers, or contacted school employment centers.

\footnotetext{
${ }^{9}$ The decline in hourly earned averaged $\$ 0.86$ for reemployed displaced male workers ages 25 to 34 , compared with $\$ 3.24(\$ 0.86+\$ 2.38)$ for those ages 50 to 61 and $\$ 5.40(\$ 0.86+\$ 4.54)$ for those age 62 and older.
} 
Job search activity does not vary much by age, except that unemployed workers age 62 or older tend to engage in fewer activities than their younger counterparts, averaging only 1.67 activities. Unemployed workers ages 50 to 61 engage in more activities, averaging 2.02, than any other age group. The likelihood that job searchers contact employers falls steadily with age. During a four-week period, 79 percent of unemployed workers ages 25 to 34 contacted employers directly, compared with 72 percent of those ages 50 to 61 and 62 percent of those age 62 or older. The oldest and youngest job searchers are less likely to contact public employment agencies than others, and those age 62 or older are much less likely to place or answer ads. Unemployed workers age 62 or older are just as likely as those ages 50 to 61 or those ages 35 to 49 to contact friends or relatives in their job search, and they are more likely than unemployed workers younger than 25 to do so.

\section{Conclusions}

The good news for older workers is that they are less likely to lose their jobs than younger workers. Between 1996 and 2007, men ages 50 to 61 are 21 percent less likely than those ages 25 to 34 to become displaced from their jobs each month, and men age 62 or older are 23 percent less likely. The story is similar for women: compared with those ages 25 to 34, women ages 50 to 61 are 30 percent less likely to lose their jobs and those age 62 or older are 13 percent less likely. The protective effects of age, however, derive solely from older workers' seniority with their employers. When we hold job tenure constant, we find that older workers are just as likely as younger workers to lose their jobs. In fact, men ages 50 to 61 are significantly more likely to become displaced from their jobs than men ages 25 to 34 with the same length of service with the employer. As long-term employment relationships become less common even at older ages (Farber 2008), the existing layoff advantage for older workers may erode further.

When older workers lose their jobs they appear to have more trouble finding work than their younger counterparts. Displaced men ages 50 to 61 are 39 percent less likely to become reemployed each month than those ages 25 to 34, and men age 62 or older are 51 percent less likely. Displaced women are 18 percent less likely to find a new job at ages 50 to 61 than at ages 25 to 34 , and 50 percent less likely at age 62 or older.

Although more research is needed to understand why older displaced workers are less likely to become reemployed than younger workers, there are several possible explanations. 
Employers may be reluctant to hire older workers because they fear they will not have time to recoup hiring and training costs before they retire. Surveys reveal that many employers believe older workers lack creativity and are generally unwilling to learn new things (Johnson 2009). Many also express concern that older workers are much more expensive than younger workers, perhaps because of rigid seniority wage structures or because pension and health benefits are more expensive at older ages (Scott, Berger, and Garen 1995). Our results, however, show that the median hourly wage for reemployed displaced workers is lower at ages 50 to 61 than at ages 35 to 49, suggesting that concern over the expense of hiring older workers may be overblown.

Another possible explanation for older workers' low reemployment probabilities is that older unemployed workers have higher reservation wages than their younger counterparts or engage in less intensive search activities. The older unemployed are wealthier than the younger unemployed, so they may be more willing to wait longer until the right job comes along, and perhaps put less effort into their job search. However, our evidence from the CPS does not support the notion that older unemployed workers (at least up to age 61) are less diligent job searchers. Unemployed workers ages 50 to 61 engage in just as many search activities as younger workers (although we are unable to measure the intensity of those activities). And even when we control for household wealth, we find that older displaced workers spend more time out of work than younger displaced workers.

Our reemployment findings are consistent with other evidence of employer reluctance to hire older workers. Several audit studies have found that employers are less likely to hire older workers than otherwise-identical younger workers (Lahey 2008; Rosen and Jerdee. 1977, 1995). In 2008, 15 percent of workers ages 55 to 61 reported in the HRS that their employers give preference to younger workers over older workers in promotion decisions (Johnson 2010). Low skilled older men are especially likely to perceive this type of discrimination: 29 percent of men who did not complete high school and 20 percent of high school graduates claimed that their employers preferred younger workers, compared with only 13 percent of men who had attended college.

When older displaced workers find jobs, they typically experience sharp wage declines. For displaced men who become reemployed, the median hourly wage on the new job falls 20 percent below the median hourly wage on the old job at ages 50 to 61 . For those reemployed at age 62 or older, the new median wage falls 36 percent below the old median wage. By contrast, 
median wages fall only 4 percent at ages 35 to 49 and 2 percent at ages 25 to 34 . Older displaced women who become reemployed also suffer sizeable wage losses, but the differences between older and younger workers are not as dramatic. Other studies have documented substantial wage losses for displaced older workers who become reemployed (Couch, Jolly, and Placzek 2009; von Wachter, Song, and Manchester 2009), but it is not yet clear what factors drive these losses. Earnings may fall sharply for older workers because the human capital they developed on their old job was specific to that particular firm and not readily transferrable to other employers. Or the wage losses may reflect employer reluctance to hire older workers. Further research should be undertaken to understand what drives these substantial wage losses.

This study covers the period 1996 to 2007, when the economy was strong except for the mild recession of 2001. Age differences in layoff probabilities and the consequences of job loss could differ today, when the demand for labor is unusually weak. We find that the 2001 recession disproportionately increased layoffs for men ages 50 to 61, relative to younger workers, and that pattern might be recurring today. Unemployment rates increased substantially for older workers in 2009, and rates for those age 65 and older increased much more rapidly during the Great Recession than in previous economic downturns (Johnson and Mommaerts 2010). More research will be necessary as data becomes available to uncover any new displacement patterns.

The employment challenges facing older workers have important implications for retirement policy. For example, the debate over increasing Social Security's retirement age is intensifying. This policy option becomes less desirable when the employment prospects for older Americans are poor. As concern over retirement income security mounts (Munnell, Webb, and Golub-Sass 2009), the option to delay retirement is increasingly viewed as the best way to increase retirement income (Butrica, Smith, and Steuerle 2006; Munnell and Sass 2008). This strategy, of course, depends crucially on older adult's ability to find work. Although many employed seniors may be able to work longer on their existing jobs, our results highlight the difficulty that older Americans without jobs face finding work. 


\section{References}

Acs, Gregory, and Nabeel Alsalam. 2010. "The Changing Profile of the Unemployed.” Paper presented at the Thirty-Second Annual APPAM Research Conference, Boston.

Allison, Paul D. 1984. Event History Analysis. Beverly Hills, CA: Sage.

Brand, Jennie E., Becca R. Levy, and William T. Gallo. 2008. "Effects of Layoffs and Plant Closings on Depression Among Older Workers." Research on Aging 30(6): 701-21.

Browning, Martin, Anne Moller Dano, and Eskil Heinesen. 2006. "Job Displacement and StressRelated Health Outcomes.” Health Economics 15(10): 1061-75.

Bureau of Labor Statistics. 2010a. "Highlights of Women's Earnings in 2009." Washington, DC: U.S. Department of Labor.

— 2010b. "Labor Force Statistics from the Current Population Survey." Washington, DC: U.S. Department of Labor. http://data.bls.gov:8080/PDQ/outside.jsp?survey=ln.

- 2010c. "Unemployed persons by Age, Sex, Race, Hispanic or Latino Ethnicity, Marital Status, and Duration of Unemployment." Washington, DC: U.S. Department of Labor. ftp://ftp.bls.gov/pub/special.requests/lf/aat31.txt.

Butrica, Barbara A., Karen E. Smith, and C. Eugene Steuerle. 2006. "Working for a Good Retirement." Washington, DC: The Urban Institute.

Card, David, and Philip B. Levine. 2000. "Extended Benefits and the Duration of UI Spells: Evidence from the New Jersey Extended Benefit Program." Journal of Public Economics 78(1-2): 107-38.

Carrington, William J. 1993. "Wage Losses for Displaced Workers: Is It Really the Firm That Matters?” Journal of Human Resources 28(3): 435-62.

Chan, Sewin, and Ann Huff Stevens. 2001. "Job Loss and Employment Patterns of Older Workers.” Journal of Labor Economics 19(2): 484-521.

Charles, Kerwin Kofi, and Melvin Stephens Jr. 2004. "Job Displacement, Disability, and Divorce." Journal of Labor Economics 22(2): 489-522.

Couch, Kenneth A., and Dana W. Placzek. 2010. "Earnings Losses of Displaced Workers Revisited." American Economic Review 100(1): 572-89.

Couch, Kenneth A., Nicholas A. Jolly, and Dana W. Placzek. 2009. "Earnings Losses of Older Displaced Workers: A Detailed Analysis with Administrative Data." Research on Aging 31(1): $17-40$. 
Eliason, Marcus, and Donald Storrie. 2007. “Does Job Loss Shorten Life?” Working Papers in Economics No. 153. Goteborg, Sweden: Goteborg University.

Elsby, Michael W. L., Bart Hobijn, and Aysegul Sahin. 2010. "The Labor Market in the Great Recession.” Brookings Papers on Economic Activity 2010 (Spring):1-48.

Falba, Tracy, Hsun Mei Teng, Jody L. Sindelar, and William T. Gallo. 2005. "The effect of involuntary job loss on smoking intensity and relapse." Addiction 100(9): 1330-39.

Farber, Henry S. 2005. "What Do We Know about Job Loss in the United States? Evidence from the Displaced Workers Survey, 1984-2004.” Industrial Relations Section Working Paper No. 498. Princeton, NJ: Princeton University.

—. 2008. "Employment Insecurity: The Decline in Worker-Firm Attachment in the United States.” Industrial Relations Section Working Paper No. 530. Princeton, NJ: Princeton University.

Farber, Henry S., Robert Hall, and John Pencavel. 1993. "The Incidence and Costs of Job Loss: 1982-91.” Brookings Papers on Economic Activity: Microeconomics 1993(1): 73-132.

Farber, Henry S., John Haltiwanger, and Katherine G. Abraham. 1997. "The Changing Face of Job Loss in the United States, 1981-1995." Brookings Papers on Economic Activity: Microeconomics 1997: 55-142.

Gallo, William T., Elizabeth H. Bradley, Michele Siegel, and Stanislav V. Kasl. 2001. “The Impact of Involuntary Job Loss on Subsequent Alcohol Consumption by Older Workers: Findings from the Health and Retirement Survey." Journal of Gerontology: Social Sciences 56(1): S3-9.

Gallo, W.T., H.M. Teng, T.A. Falba, S.V. Kasl, H.M. Krumholz, and E.H. Bradley. 2006. “The Impact of Late Career Job Loss on Myocardial Infarction and Stroke: A 10-Year Follow Up Using the Health and Retirement Survey." Occupational and Environmental Medicine 63(10): 683-87.

Gibbons, Robert, and Lawrence F. Katz. 1991. "Layoffs and Lemons." Journal of Labor Economics 9(4): 351-80.

Heidkamp, Maria, Nicole Corre, and Carl E. Van Horn. 2010. 'The 'New Unemployables:' Older Job Seekers Struggle to Find Work during the Great Recession.” Issue Brief 25. Chestnut Hill, MA: Sloan Center on Aging and Work at Boston College.

Hu, Luojia, and Christopher Taber. 2005. "Layoffs, Lemons, Race, and Gender." NBER Working Paper No. 11481. Cambridge, MA: National Bureau of Economic Research.

Jacobson, Louis S., Robert J. LaLonde, and Daniel G. Sullivan. 1993. "Earnings Losses of Displaced Workers." American Economic Review 83(4): 685-709. 
Johnson, Richard W. 2009. "Managerial Attitudes Toward Older Workers: A Review of the Evidence." In Aging and Work: Issues and Implications in a Changing Landscape, edited by Sara J. Czaja and Joseph Sharit (185-208). Baltimore: Johns Hopkins University Press.

_. 2010. "Older Workers: Opportunities and Challenges.” Washington, DC: The Urban Institute.

Johnson, Richard W., and Gordon B. T. Mermin. 2009. "Financial Hardship Before and After Social Security's Early Eligibility Age.” Washington, D.C.: The Urban Institute.

Johnson, Richard W., and Corina Mommaerts. 2010. "How Did Older Workers Fare in 2009?" Washington, DC: The Urban Institute.

Johnson, Richard W., Janette Kawachi, and Eric K. Lewis. 2009. “Older Workers on the Move: Recareering in Later Life.” AARP Public Policy Report. Washington, DC: AARP.

Karoly, Lynn A. and Julie Zissimopoulos. 2004. "Self-Employment Among Older U.S. Workers." Monthly Labor Review 127(7): 24-47.

Katz, Lawrence F., and Bruce D. Meyer. 1990. "The Impact of the Potential Duration of Unemployment Benefits on the Duration of Unemployment." Journal of Public Economics 41(1): 45-72.

Lahey, Joanna. 2008. “Age, Women, and Hiring: An Experimental Study.” Journal of Human Resources 43(1): 30-56.

Lalive, Rafael, Jan van Ours, and Josef Zweimuller. 2006. "How Changes in Financial Incentives Affect the Duration of Unemployment." Review of Economic Studies 73(4): 1009-38.

Maestas, Nicole, and Xiaoyan Li. 2006. "Discouraged Workers? Job Search Outcomes of Older Workers.” WP 2006-133. Ann Arbor, MI: Michigan Retirement Research Center.

Michaelides, Marios, and Peter Mueser. 2009. "Recent Changes in the Characteristics of Unemployed Workers.” http://economics.missouri.edu/workingpapers/2009/WP0912_Mueser.pdf.

Moffitt, Robert. 1985. "Unemployment Insurance and the Distribution of Unemployment Spells." Journal of Econometrics 28(1): 85-101.

Mortensen, Dale T. 1977. "Unemployment Insurance and Job Search Decisions.” Industrial and Labor Relations Review 30(4): 505-17.

Munnell, Alicia H., and Steven A. Sass . 2008. Working Longer: The Solution to the Retirement Income Challenge. Washington, DC: Brookings Institution Press. 
Munnell, Alicia H., Anthony Webb, and Francesca Golub-Sass. 2009. “The National Retirement Risk Index: After the Crash." Chestnut Hill, MA: Center for Retirement Research at Boston College.

Munnell, Alicia H., Steven Sass, Mauricio Soto, and Natalia Zhivan. 2006. "Has the Displacement of Older Workers Increased?” CRR Working Paper No. 2006-17. Chestnut Hill, MA: Center for Retirement Research at Boston College.

Neal, Derek. 1995. "Industry-Specific Human Capital: Evidence from Displaced Workers." Journal of Labor Economics 13(4): 653-77

Podgursky, Michael, and Paul Swaim. 1987. "Job Displacement and Earnings Loss: Evidence from the Displaced Worker Survey." Industrial and Labor Relations Review 41(1): 1729.

Rodriguez, Daniel, and Madeline Zavodny. 2003. "Changes in the Age and Education Profile of Displaced Workers.” Industrial and Labor Relations Review 56(3): 498-510.

Rosen, Benson, and Thomas H. Jerdee. 1977. “Too Old or Not Too Old?” Harvard Business Review 55(6): 97-106.

- 1995. "The Persistence of Age and Sex Stereotypes in the 1990s: The Influence of Age and Gender in Management Decisionmaking." Public Policy Institute Issue Brief No. 22. Washington, DC: AARP.

Ruhm, Christopher J. 1991. “Are Workers Permanently Scarred by Job Displacements?” American Economic Review 81(1): 319-24.

Sahin, Aysegul, Joseph Song, and Bart Hobijn. 2010. "The Unemployment Gender Gap during the 2007 Recession." Current Issues in Economics and Finance 16(2): 1-7.

Salm, Martin. 2009. “Does Job Loss Cause Ill Health?” Health Economics 18(9): 1075-89.

Schwartz, Jeremy. 2010. "Do Temporary Extensions to Unemployment Insurance Benefits Alter Search Behavior? The Effects of the Standby Extended Benefit Program in the United States." Baltimore: Loyola University Maryland.

Scott, Frank A., Mark C. Berger, and John E. Garen. 1995. "Do Health Insurance and Pension Costs Reduce Job Opportunities of Older Workers?” Industrial and Labor Relations Review 48(4): 775-91.

Shierholz, Heidi. 2010. "Job Growth Improves, but Pace Leaves Full Employment 20 years Away." Washington, DC: Economic Policy Institute.

Stevens, Ann Huff. 1997. "Persistent Effects of Job Displacement: The Importance of Multiple Job Losses.” Journal of Labor Economics 15(1): 165-88. 
Sullivan, Daniel, and Till M. von Wachter. 2009. "Job Displacement and Mortality: An Analysis Using Administrative Data.” Quarterly Journal of Economics 124(3): 1265-1306.

von Wachter, Till, and Elizabeth Weber Handwerker. 2009. "Variation in the Cost of Job Loss by Worker Skill: Evidence Using Matched Data from California, 1991-2000.” Department of Economics Discussion Paper Series. New York: Columbia University.

von Wachter, Till, Jae Song, and Joyce Manchester. 2009. "Long-Term Earnings Losses due to Mass Layoffs During the 1982 Recession: An Analysis Using U.S. Administrative Data from 1974 to 2004.” Department of Economics Discussion Paper Series. New York: Columbia University. 
Figure 1. Cumulative Probability of Male Wage and Salary Workers Being Displaced from Their Jobs, by Age

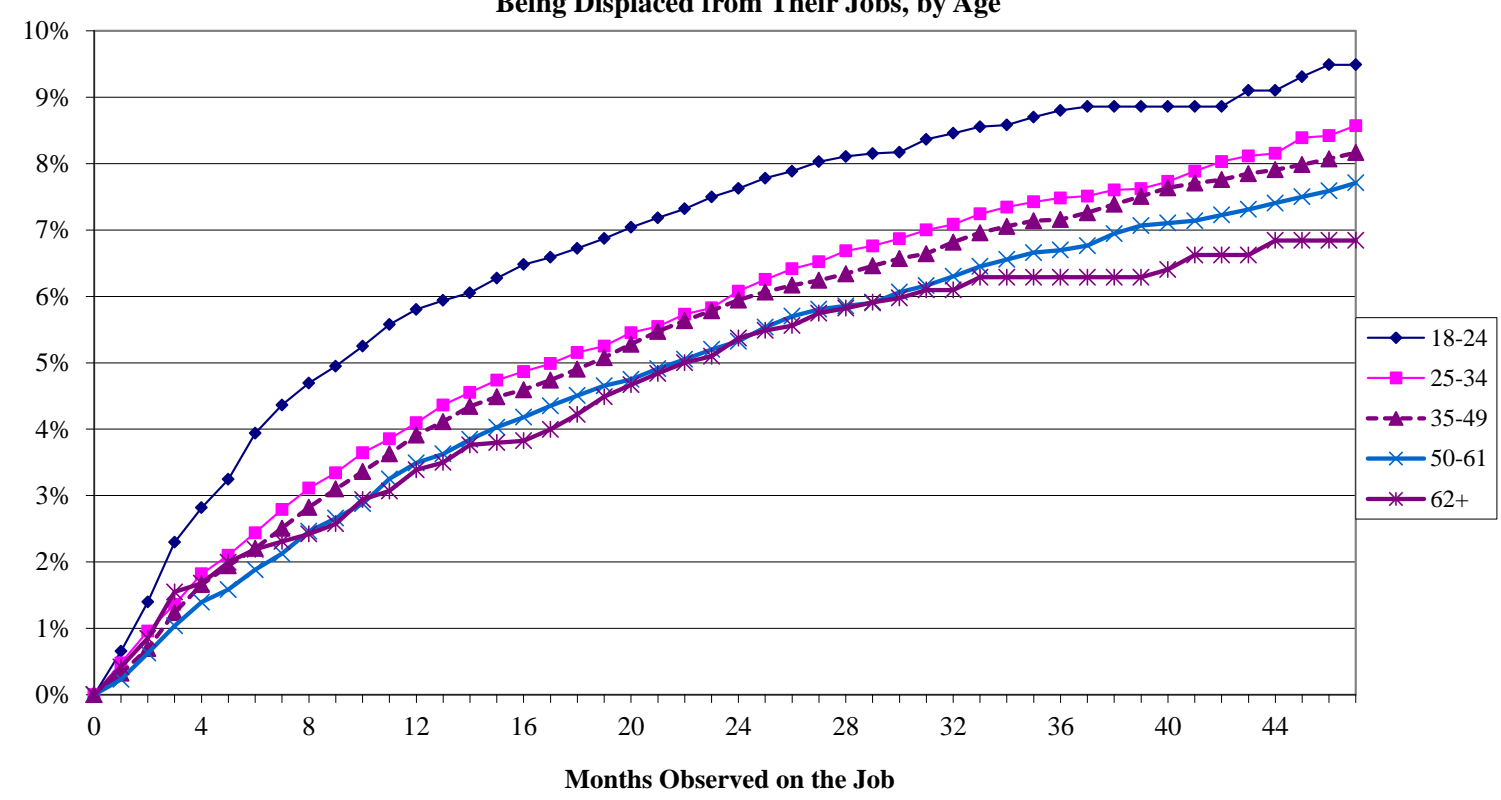

Source: Authors' estimates from the the 1996, 2001, and 2004 SIPP panels, spanning the years 1996 to 2007.

Note: The analysis follows men age 18 and older from the first month they are observed employed in a wage and salary job until they leave the job, they drop out of the survey, or the survey ends. We classify workers as displaced if they left their jobs because of layoff, slack work, or employer bankuptcy, or because their employer sold the business.

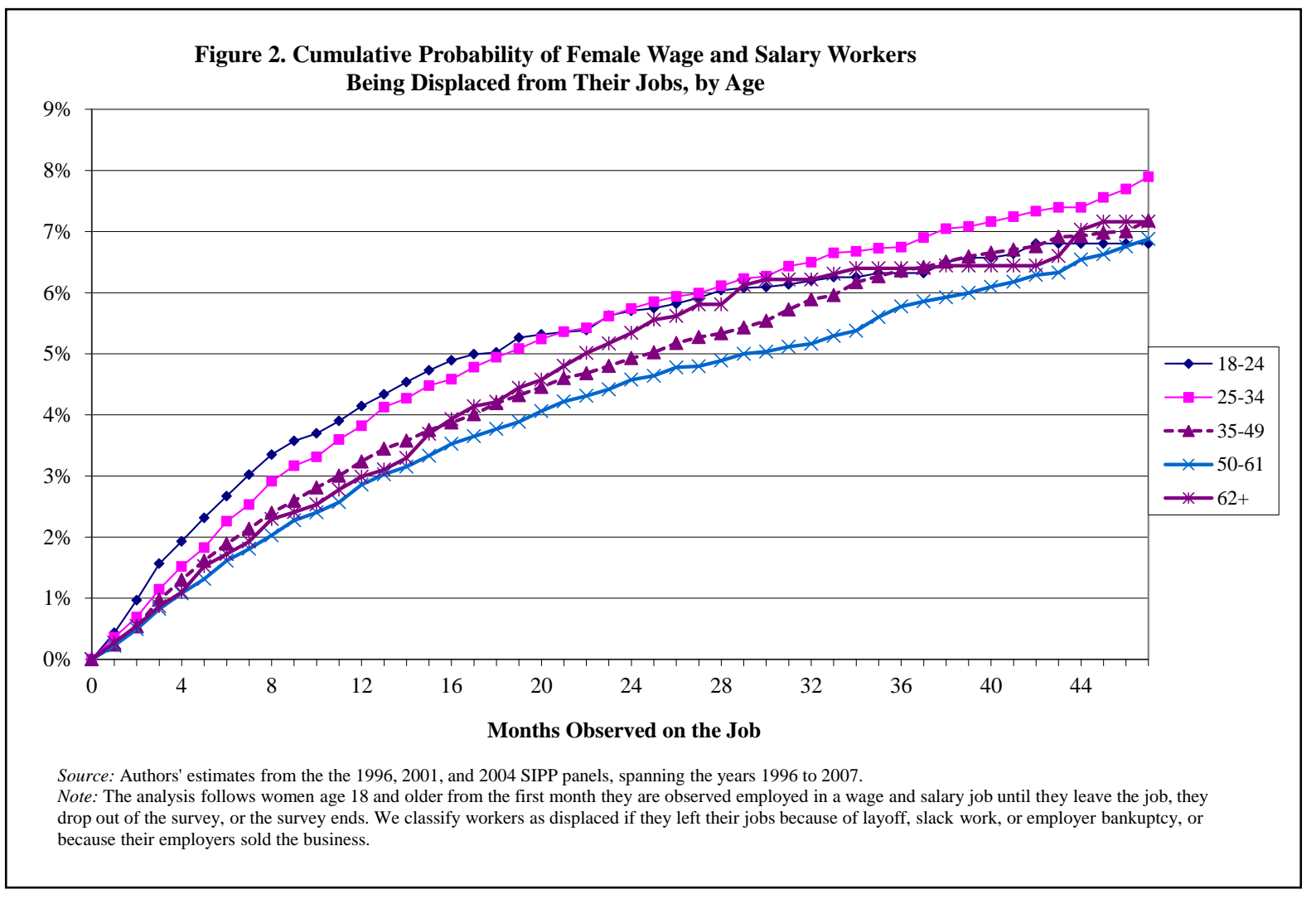




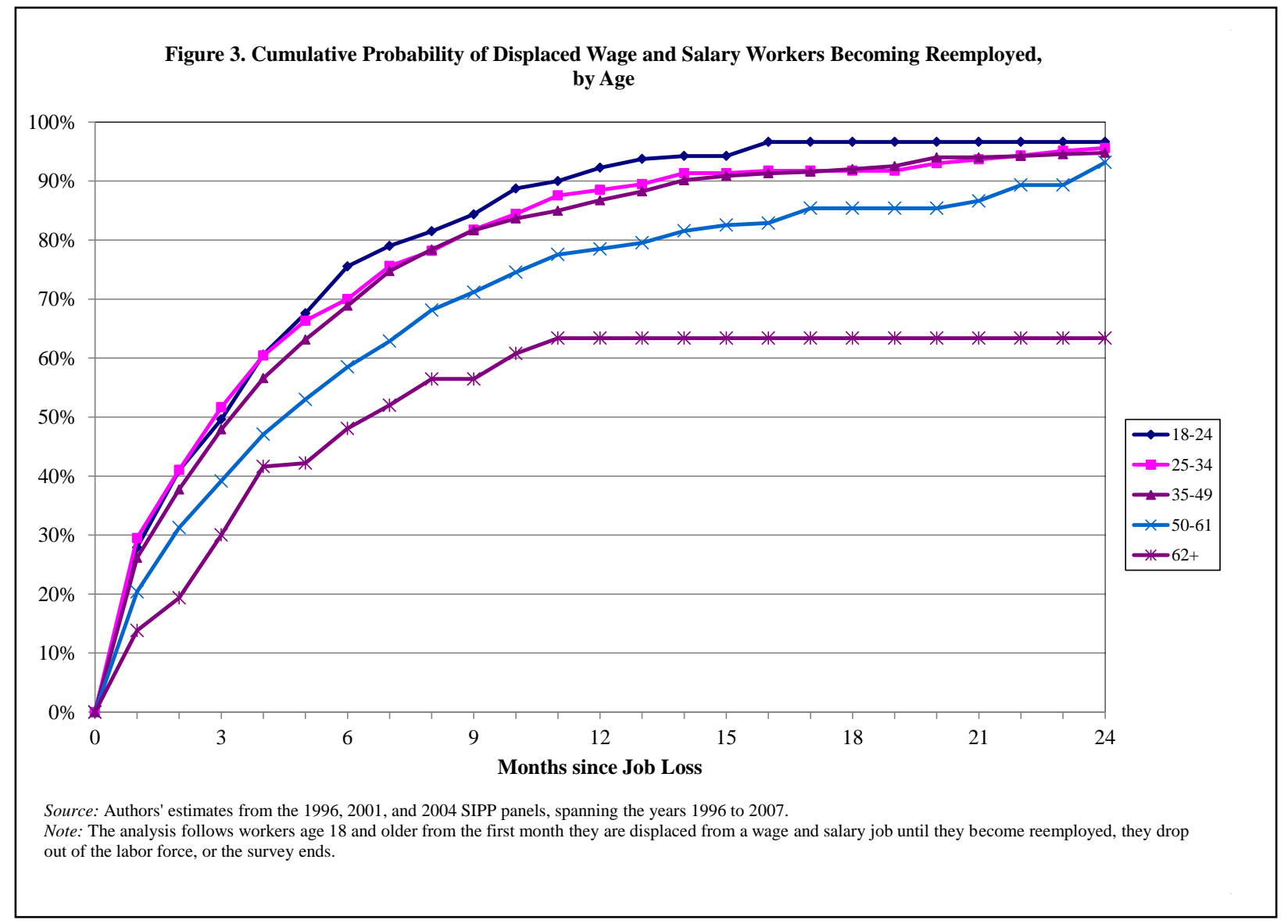


Table 1. Characteristics of Job Displacement Sample

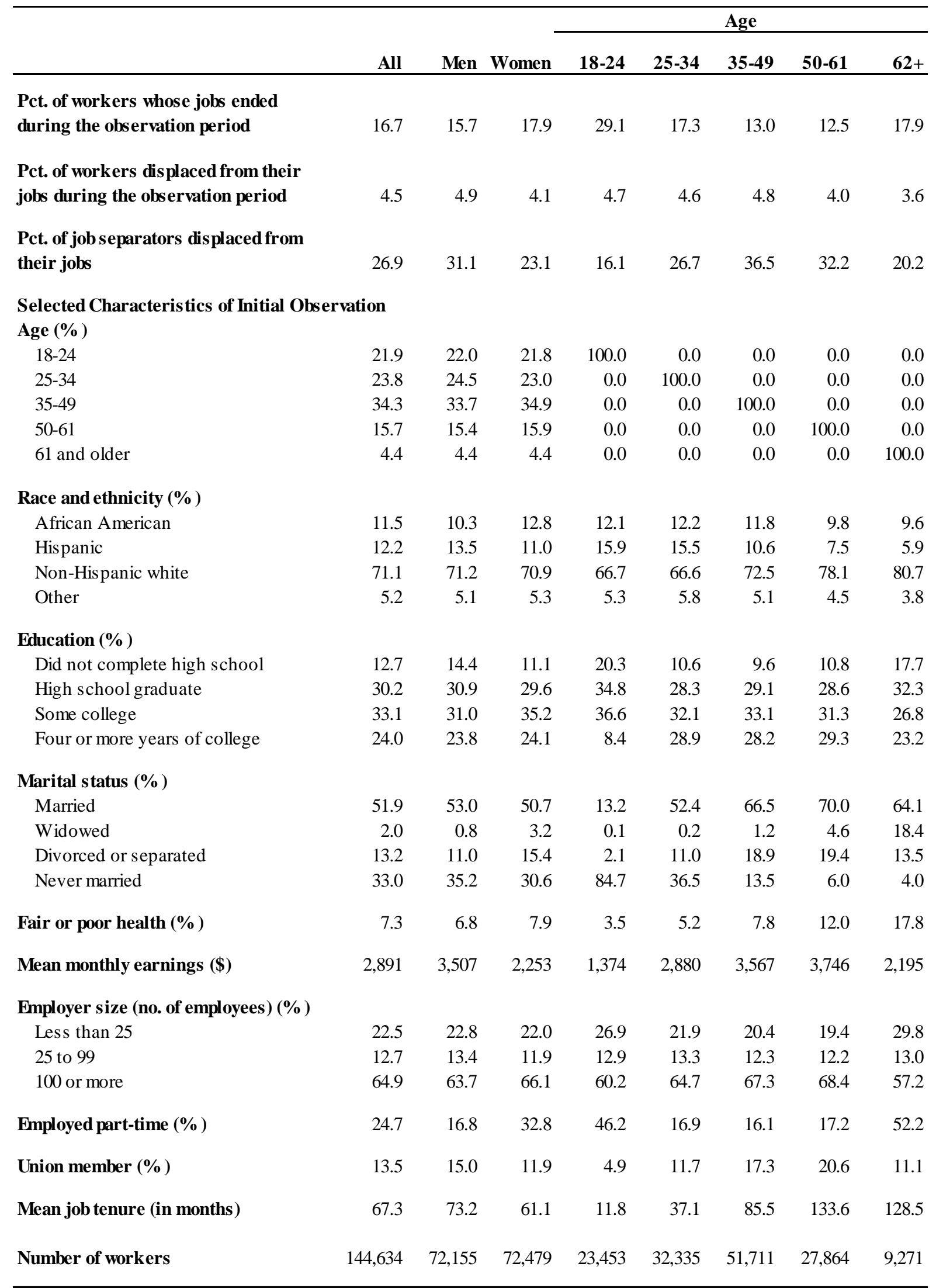

Source: Authors' estimates from the 1996, 2001, and 2004 SIPP panels, spanning the years 1996 to 2007.

Note: The sample is restricted to workers age 18 and older employed in wage and salary jobs. Financial amounts are measured in constant 2009 dollars. 
Table 2. Estimated Marginal Efrfects on the Likelihood of Being Displaced from One's Job, Male Wage and Salary Workers Age 18 and Older

\begin{tabular}{|c|c|c|c|c|c|}
\hline & (1) & (2) & (3) & (4) & (5) \\
\hline \multicolumn{6}{|l|}{ Age } \\
\hline $18-24$ & $\begin{array}{l}0.121 * * \\
(0.016)\end{array}$ & $\begin{array}{l}0.062 * * \\
(0.014)\end{array}$ & $\begin{array}{l}0.036 * * \\
(0.012)\end{array}$ & $\begin{array}{l}0.013 \\
(0.010)\end{array}$ & $\begin{array}{l}0.011 \\
(0.015)\end{array}$ \\
\hline [Reference: 25-34] & --- & --- & --- & --- & --- \\
\hline $35-49$ & $\begin{array}{l}-0.026^{* *} \\
(0.009)\end{array}$ & $\begin{array}{l}-0.016^{*} \\
(0.009)\end{array}$ & $\begin{array}{l}-0.010 \\
(0.008)\end{array}$ & $\begin{array}{l}0.031 * * \\
(0.007)\end{array}$ & $\begin{array}{l}0.015 \\
(0.012)\end{array}$ \\
\hline $50-61$ & $\begin{array}{l}-0.049 * * \\
(0.001)\end{array}$ & $\begin{array}{l}-0.038 * * \\
(0.010)\end{array}$ & $\begin{array}{l}-0.025^{* *} \\
(0.010)\end{array}$ & $\begin{array}{l}0.055^{* *} \\
(0.011)\end{array}$ & $\begin{array}{l}0.022 \\
(0.016)\end{array}$ \\
\hline 62 and older & $\begin{array}{l}-0.052 * * \\
(0.014)\end{array}$ & $\begin{array}{l}-0.053 * * \\
(0.014)\end{array}$ & $\begin{array}{l}-0.069 * * \\
(0.012)\end{array}$ & $\begin{array}{l}0.005 \\
(0.015)\end{array}$ & $\begin{array}{l}-0.001 \\
(0.023)\end{array}$ \\
\hline \multicolumn{6}{|l|}{ Race and ethnicity } \\
\hline African American & --- & $\begin{array}{l}0.009 \\
(0.012)\end{array}$ & $\begin{array}{l}0.032 * * \\
(0.012)\end{array}$ & $\begin{array}{l}0.022 * * \\
(0.010)\end{array}$ & $\begin{array}{l}0.021 * * \\
(0.010)\end{array}$ \\
\hline Hispanic & --- & $\begin{array}{l}0.012 \\
(0.011)\end{array}$ & $\begin{array}{l}0.008 \\
(0.010)\end{array}$ & $\begin{array}{l}-0.001 \\
(0.008)\end{array}$ & $\begin{array}{l}-0.001 \\
(0.008)\end{array}$ \\
\hline [Reference: Non-His panic white] & --- & --- & --- & --- & --- \\
\hline Other & --- & $\begin{array}{l}0.010 \\
(0.016)\end{array}$ & $\begin{array}{l}0.014 \\
(0.012)\end{array}$ & $\begin{array}{l}-0.002 \\
(0.012)\end{array}$ & $\begin{array}{l}-0.002 \\
(0.012)\end{array}$ \\
\hline \multicolumn{6}{|l|}{ Education } \\
\hline Not high school graduate & --- & $\begin{array}{l}0.067 * * \\
(0.013)\end{array}$ & $\begin{array}{l}0.028 * * \\
(0.010)\end{array}$ & $\begin{array}{l}0.020 * * \\
(0.009)\end{array}$ & $\begin{array}{l}0.021 * * \\
(0.009)\end{array}$ \\
\hline [Ref: High school graduate] & --- & --- & --- & --- & --- \\
\hline Some college & --- & $\begin{array}{l}-0.035 * * \\
(0.008)\end{array}$ & $\begin{array}{l}-0.010 \\
(0.008)\end{array}$ & $\begin{array}{l}-0.012 * \\
(0.006)\end{array}$ & $\begin{array}{l}-0.012 * \\
(0.006)\end{array}$ \\
\hline 4 or more years of college & --- & $\begin{array}{l}-0.099 * * \\
(0.001)\end{array}$ & $\begin{array}{l}-0.037 * * \\
(0.010)\end{array}$ & $\begin{array}{l}-0.042 * * \\
(0.008)\end{array}$ & $\begin{array}{l}-0.042 * * \\
(0.008)\end{array}$ \\
\hline \multicolumn{6}{|l|}{ Marital status } \\
\hline [Reference: Married] & --- & --- & --- & --- & --- \\
\hline Widowed & --- & $\begin{array}{l}0.073 \\
(0.045)\end{array}$ & $\begin{array}{l}0.060 \\
(0.040)\end{array}$ & $\begin{array}{l}0.060 \\
(0.035)\end{array}$ & $\begin{array}{l}0.035 * * \\
(0.010)\end{array}$ \\
\hline Divorced or separated & --- & $\begin{array}{l}0.084 * * \\
(0.013)\end{array}$ & $\begin{array}{l}0.065 * * \\
(0.012)\end{array}$ & $\begin{array}{l}0.040 \\
(0.010)\end{array}$ & $\begin{array}{l}0.022 * * \\
(008)\end{array}$ \\
\hline Never married & --- & $\begin{array}{l}0.053 * * \\
(0.010)\end{array}$ & $\begin{array}{l}0.033 * * \\
(0.009)\end{array}$ & $\begin{array}{l}0.021 * * \\
(0.008)\end{array}$ & $\begin{array}{l}0.022 * * \\
(0.008)\end{array}$ \\
\hline \multicolumn{6}{|l|}{ Region } \\
\hline Northeast & --- & $\begin{array}{l}0.036 * * \\
(0.011)\end{array}$ & $\begin{array}{l}0.047 * * \\
(0.011)\end{array}$ & $\begin{array}{l}0.037 * * \\
(0.009)\end{array}$ & $\begin{array}{l}0.037 * * \\
(0.009)\end{array}$ \\
\hline [Reference: Midwest] & --- & --- & --- & --- & --- \\
\hline South & --- & $\begin{array}{l}0.0008 \\
(0.009)\end{array}$ & $\begin{array}{l}0.002 \\
(0.008)\end{array}$ & $\begin{array}{l}-0.003 \\
(0.007)\end{array}$ & $\begin{array}{l}-0.003 \\
(0.007)\end{array}$ \\
\hline West & --- & $\begin{array}{l}0.034 * * \\
(0.011)\end{array}$ & $\begin{array}{l}0.040 * * \\
(0.010)\end{array}$ & $\begin{array}{l}0.025^{* *} \\
(0.009)\end{array}$ & $\begin{array}{l}0.025 * * \\
(0.008)\end{array}$ \\
\hline
\end{tabular}


Table 2 (continued).

\begin{tabular}{|c|c|c|c|c|c|}
\hline & (1) & (2) & (3) & (4) & (5) \\
\hline Fair or poor health & & $\begin{array}{l}0.049 * * \\
(0.015)\end{array}$ & $\begin{array}{l}0.027 * * \\
(0.013)\end{array}$ & $\begin{array}{l}0.019 * \\
(0.011)\end{array}$ & $\begin{array}{l}0.019 * \\
(0.011)\end{array}$ \\
\hline Natural log of monthly earnings & --- & --- & $\begin{array}{l}-0.023 * * \\
(0.002)\end{array}$ & $\begin{array}{l}-0.017 * * \\
(0.001)\end{array}$ & $\begin{array}{l}-0.017 * * \\
(0.001)\end{array}$ \\
\hline \multicolumn{6}{|l|}{ Employer size (no. of employees) } \\
\hline Less than 25 & --- & --- & $\begin{array}{l}0.067 * * \\
(0.009)\end{array}$ & $\begin{array}{l}0.044 * * \\
(0.008)\end{array}$ & $\begin{array}{l}0.044 * * \\
(0.008)\end{array}$ \\
\hline 25 to 99 & --- & --- & $\begin{array}{l}0.049 * * \\
(0.011)\end{array}$ & $\begin{array}{l}0.028 * * \\
(0.009)\end{array}$ & $\begin{array}{l}0.028 * * \\
(0.009)\end{array}$ \\
\hline [Reference: 100 or more] & --- & --- & --- & --- & --- \\
\hline Part-time employment & --- & --- & $\begin{array}{l}0.054^{* *} \\
(0.011)\end{array}$ & $\begin{array}{l}0.028 * * \\
(0.009)\end{array}$ & $\begin{array}{l}0.028 * * \\
(0.009)\end{array}$ \\
\hline Union member & --- & --- & $\begin{array}{l}-0.042 * * \\
(0.008)\end{array}$ & $\begin{array}{l}-0.001 \\
(0.008)\end{array}$ & $\begin{array}{l}-0.001 \\
(0.008)\end{array}$ \\
\hline Job tenure (months) & --- & --- & --- & $\begin{array}{l}-0.001 * * \\
(0.00004)\end{array}$ & $\begin{array}{l}-0.001 * * \\
(0.00004)\end{array}$ \\
\hline \multicolumn{6}{|l|}{ Year } \\
\hline [Reference: 1996-2000] & --- & --- & --- & --- & --- \\
\hline $2001-2003$ & $\begin{array}{l}0.094 * * \\
(0.010)\end{array}$ & $\begin{array}{l}0.090 * * \\
(0.010)\end{array}$ & $\begin{array}{l}0.086^{* * *} \\
(0.009)\end{array}$ & $\begin{array}{l}0.067 * * \\
(0.008)\end{array}$ & $\begin{array}{l}0.046^{* *} \\
(0.014)\end{array}$ \\
\hline 2004-2007 & $\begin{array}{l}-0.009 \\
(0.009)\end{array}$ & $\begin{array}{l}-0.003 \\
(0.008)\end{array}$ & $\begin{array}{l}-0.007 \\
(0.008)\end{array}$ & $\begin{array}{l}-0.011 * \\
(0.007)\end{array}$ & $\begin{array}{l}-0.026^{* *} \\
(0.013)\end{array}$ \\
\hline \multicolumn{6}{|l|}{ Year-Age Interactions } \\
\hline Age $18-24 *$ Year 2001-2003 & --- & --- & --- & --- & $\begin{array}{l}0.002 \\
(0.020)\end{array}$ \\
\hline Age $35-49 *$ Year $2001-2003$ & --- & --- & --- & --- & $\begin{array}{l}0.027 \\
(0.018)\end{array}$ \\
\hline Age $50-61 *$ Year 2001-2003 & --- & --- & --- & --- & $\begin{array}{l}0.063 * * \\
(0.027)\end{array}$ \\
\hline Age $62+*$ Year 2001-2003 & --- & --- & --- & --- & $\begin{array}{l}-0.014 \\
(0.031)\end{array}$ \\
\hline Age $18-24 *$ Year 2004-2007 & --- & --- & --- & --- & $\begin{array}{l}0.004 \\
(0.021)\end{array}$ \\
\hline Age $35-49 *$ Year 2004-2007 & --- & --- & --- & --- & $\begin{array}{l}0.023 \\
(0.019)\end{array}$ \\
\hline Age $50-61 *$ Year 2004-2007 & --- & --- & --- & --- & $\begin{array}{l}0.032 \\
(0.024)\end{array}$ \\
\hline Age 62+* Year 2004-2007 & --- & --- & --- & --- & $\begin{array}{l}0.034 \\
(0.038)\end{array}$ \\
\hline $\begin{array}{l}\text { Occupation and industry } \\
\text { controls }\end{array}$ & No & No & Yes & Yes & Yes \\
\hline $\mathrm{N}$ & $1,743,700$ & $1,743,700$ & $1,743,700$ & $1,743,700$ & $1,743,700$ \\
\hline Pseudo r-squared & 0.0060 & 0.0129 & 0.0265 & 0.0411 & 0.0413 \\
\hline Mean of dep. variable (times 100) & 0.231 & 0.231 & 0.231 & 0.231 & 0.231 \\
\hline
\end{tabular}

Source: Authors' tabulations from the 1996, 2001, and 2004 SIPP panels, spanning the years 1996-2007.

Notes: Cell entries show the percentage point impact of each variable on the likelihood of losing one's job because of layoff, slack work, or employer bankruptcy, or because the employer sold the business, based on discrete-time hazard models. Standard errors are in parenetheses. Models are estimated as logits. All financial amounts are measured in constant 2009 dollars.

$* * p<.05 ; * .10>p>.05$ 
Table 3. Estimated Marginal Efrfects on the Likelihood of Being Displaced from One's Job, Female Wage and Salary Workers Age 18 and Older

\begin{tabular}{|c|c|c|c|c|c|}
\hline & (1) & (2) & (3) & (4) & (5) \\
\hline \multicolumn{6}{|l|}{ Age } \\
\hline $18-24$ & $\begin{array}{l}0.047 * * \\
(0.013)\end{array}$ & $\begin{array}{c}0.011 \\
(0.012)\end{array}$ & $\begin{array}{l}-0.007 \\
(0.010)\end{array}$ & $\begin{array}{l}-0.017 * * \\
(0.008)\end{array}$ & $\begin{array}{l}-0.010 \\
(0.014)\end{array}$ \\
\hline [Reference: $25-34]$ & --- & --- & --- & --- & --- \\
\hline $35-49$ & $\begin{array}{l}-0.030 * * \\
(0.008)\end{array}$ & $\begin{array}{l}-0.030 * * \\
(0.008)\end{array}$ & $\begin{array}{l}-0.019 * * \\
(0.007)\end{array}$ & $\begin{array}{c}0.008 \\
(0.007)\end{array}$ & $\begin{array}{c}0.015 \\
(0.011)\end{array}$ \\
\hline $50-61$ & $\begin{array}{l}-0.059 * * \\
(0.009)\end{array}$ & $\begin{array}{l}-0.060 * * \\
(0.008)\end{array}$ & $\begin{array}{l}-0.042^{* *} \\
(0.008)\end{array}$ & $\begin{array}{c}0.011 \\
(0.009)\end{array}$ & $\begin{array}{c}0.023 \\
(0.015)\end{array}$ \\
\hline 62 and older & $\begin{array}{l}-0.026^{*} \\
(0.014)\end{array}$ & $\begin{array}{l}-0.042 * * \\
(0.012)\end{array}$ & $\begin{array}{l}-0.045^{* *} \\
(0.010)\end{array}$ & $\begin{array}{c}0.020 \\
(0.014)\end{array}$ & $\begin{array}{c}0.018 \\
(0.023)\end{array}$ \\
\hline \multicolumn{6}{|l|}{ Race and ethnicity } \\
\hline African American & --- & $\begin{array}{l}0.031 * * \\
(0.010)\end{array}$ & $\begin{array}{l}0.055^{* *} \\
(0.010)\end{array}$ & $\begin{array}{l}0.050 * * \\
(0.009)\end{array}$ & $\begin{array}{l}0.050 * * \\
(0.009)\end{array}$ \\
\hline Hispanic & --- & $\begin{array}{l}0.035 * * \\
(0.011)\end{array}$ & $\begin{array}{l}0.028 * * \\
(0.010)\end{array}$ & $\begin{array}{l}0.020 * * \\
(0.009)\end{array}$ & $\begin{array}{l}0.020 * * \\
(0.009)\end{array}$ \\
\hline [Reference: Non-Hispanic white] & --- & --- & --- & --- & --- \\
\hline Other & & $\begin{array}{c}0.001 \\
(0.014)\end{array}$ & $\begin{array}{l}-0.004 \\
(0.012)\end{array}$ & $\begin{array}{l}-0.011 \\
(0.011)\end{array}$ & $\begin{array}{l}-0.012 \\
(0.011)\end{array}$ \\
\hline \multicolumn{6}{|l|}{ Education } \\
\hline Not high school graduate & --- & $\begin{array}{l}0.120 * * \\
(0.015)\end{array}$ & $\begin{array}{l}0.079 * * \\
(0.013)\end{array}$ & $\begin{array}{l}0.061 * * \\
(0.011)\end{array}$ & $\begin{array}{l}0.061 * * \\
(0.011)\end{array}$ \\
\hline \multicolumn{6}{|l|}{ [Reference: High school graduate] } \\
\hline Some college & --- & $\begin{array}{l}-0.030 * * \\
(0.007)\end{array}$ & $\begin{array}{l}-0.010 \\
(0.007)\end{array}$ & $\begin{array}{l}-0.011 * \\
(0.006)\end{array}$ & $\begin{array}{l}-0.011 * \\
(0.006)\end{array}$ \\
\hline 4 or more years of college & --- & $\begin{array}{l}-0.092 * * \\
(0.007)\end{array}$ & $\begin{array}{l}-0.036 * * \\
(0.008)\end{array}$ & $\begin{array}{l}-0.037 * * \\
(0.007)\end{array}$ & $\begin{array}{l}-0.037 * * \\
(0.007)\end{array}$ \\
\hline \multicolumn{6}{|l|}{ Marital Status } \\
\hline [Reference: Married] & --- & --- & --- & --- & --- \\
\hline Widowed & --- & $\begin{array}{l}-0.003 \\
(0.017)\end{array}$ & $\begin{array}{c}0.0003 \\
(0.016)\end{array}$ & $\begin{array}{l}-0.004 \\
(0.014)\end{array}$ & $\begin{array}{l}-0.004 \\
(0.014)\end{array}$ \\
\hline Divorced or separated & --- & $\begin{array}{l}0.044 * * \\
(0.010)\end{array}$ & $\begin{array}{l}0.044 * * \\
(0.009)\end{array}$ & $\begin{array}{l}0.032 * * \\
(0.008)\end{array}$ & $\begin{array}{l}0.032 * * \\
(0.008)\end{array}$ \\
\hline Never married & --- & $\begin{array}{l}0.032 * * \\
(0.010)\end{array}$ & $\begin{array}{l}0.031 * * \\
(0.009)\end{array}$ & $\begin{array}{l}0.026 * * \\
(0.008)\end{array}$ & $\begin{array}{l}0.026 * * \\
(0.008)\end{array}$ \\
\hline \multicolumn{6}{|l|}{ Region } \\
\hline Northeast & --- & $\begin{array}{l}0.046^{* *} \\
(0.011)\end{array}$ & $\begin{array}{l}0.049 * * \\
(0.010)\end{array}$ & $\begin{array}{l}0.042 * * \\
(0.009)\end{array}$ & $\begin{array}{l}0.042 * * \\
(0.009)\end{array}$ \\
\hline [Reference: Midwest] & --- & --- & --- & --- & --- \\
\hline South & --- & $\begin{array}{c}0.017 * \\
(0.009)\end{array}$ & $\begin{array}{c}0.011 \\
(0.008)\end{array}$ & $\begin{array}{c}0.007 \\
(0.007)\end{array}$ & $\begin{array}{c}0.007 \\
(0.007)\end{array}$ \\
\hline West & --- & $\begin{array}{l}0.062 * * \\
(0.011)\end{array}$ & $\begin{array}{l}0.059 * * \\
(0.010)\end{array}$ & $\begin{array}{l}0.046 * * \\
(0.009)\end{array}$ & $\begin{array}{l}0.046^{* *} \\
(0.009)\end{array}$ \\
\hline
\end{tabular}


Table 3 (continued).

\begin{tabular}{|c|c|c|c|c|c|}
\hline & (1) & (2) & (3) & (4) & (5) \\
\hline Fair or poor health & --- & $\begin{array}{l}0.058^{* *} \\
(0.013)\end{array}$ & $\begin{array}{l}0.043 * * \\
(0.011)\end{array}$ & $\begin{array}{l}0.034^{* *} \\
(0.010)\end{array}$ & $\begin{array}{l}0.034^{* *} \\
(0.010)\end{array}$ \\
\hline Natural log of earnings & --- & --- & $\begin{array}{l}-0.015^{* *} \\
(0.001)\end{array}$ & $\begin{array}{l}-0.011 * * \\
(0.001)\end{array}$ & $\begin{array}{l}-0.011^{* *} \\
(0.001)\end{array}$ \\
\hline \multicolumn{6}{|l|}{ Employer size (no. of employees) } \\
\hline Fewer than 25 & --- & --- & $\begin{array}{l}0.052 * * \\
(0.008)\end{array}$ & $\begin{array}{l}0.037 * * \\
(0.007)\end{array}$ & $\begin{array}{l}0.037 * * \\
(0.007)\end{array}$ \\
\hline 25 to 99 & --- & --- & $\begin{array}{l}0.029 * * \\
(0.009)\end{array}$ & $\begin{array}{l}0.017 * * \\
(0.008)\end{array}$ & $\begin{array}{l}0.017 * * \\
(0.008)\end{array}$ \\
\hline [Reference: 100 or more] & --- & --- & --- & --- & --- \\
\hline Part-time employment & --- & --- & $\begin{array}{l}0.033 * * \\
(0.007)\end{array}$ & $\begin{array}{l}0.018^{* *} \\
(0.006)\end{array}$ & $\begin{array}{l}0.018^{* *} \\
(0.006)\end{array}$ \\
\hline Union member & --- & --- & $\begin{array}{l}-0.096 * * \\
(0.007)\end{array}$ & $\begin{array}{l}-0.070 * * \\
(0.007)\end{array}$ & $\begin{array}{l}-0.070 * * \\
(0.007)\end{array}$ \\
\hline Job tenure (months) & --- & --- & --- & $\begin{array}{l}-0.001 * * \\
(0.0004)\end{array}$ & $\begin{array}{l}-0.001 * * \\
(0.0004)\end{array}$ \\
\hline \multicolumn{6}{|l|}{ Year } \\
\hline [Reference: 1996-2000] & --- & --- & --- & --- & --- \\
\hline $2001-2003$ & $\begin{array}{l}0.079 * * \\
(0.010)\end{array}$ & $\begin{array}{l}0.076^{* *} * \\
(0.009)\end{array}$ & $\begin{array}{l}0.073^{* *} \\
(0.008)\end{array}$ & $\begin{array}{l}0.059 * * \\
(0.007)\end{array}$ & $\begin{array}{l}0.067 * * \\
(0.015)\end{array}$ \\
\hline 2004-2007 & $\begin{array}{l}-0.005 \\
(0.008)\end{array}$ & $\begin{array}{c}0.006 \\
(0.008)\end{array}$ & $\begin{array}{l}-0.0004 \\
(0.008)\end{array}$ & $\begin{array}{l}-0.005 \\
(0.007)\end{array}$ & $\begin{array}{l}0.004 \\
(0.013)\end{array}$ \\
\hline \multicolumn{6}{|l|}{ Year-Age Interactions } \\
\hline Age $18-24 *$ Year $2001-2003$ & --- & --- & --- & --- & $\begin{array}{l}-0.010 \\
(0.019)\end{array}$ \\
\hline Age $35-49 *$ Year $2001-2003$ & --- & --- & --- & --- & $\begin{array}{l}-0.006 \\
(0.015)\end{array}$ \\
\hline Age $50-61 *$ Year 2001-2003 & --- & --- & --- & --- & $\begin{array}{l}-0.016 \\
(0.017)\end{array}$ \\
\hline Age $62+*$ Year 2001-2003 & --- & --- & --- & --- & $\begin{array}{l}-0.007 \\
(0.028)\end{array}$ \\
\hline Age 18-24* Year 2004-2007 & --- & --- & --- & --- & $\begin{array}{l}-0.010 \\
(0.019)\end{array}$ \\
\hline Age $35-49 *$ Year $2004-2007$ & --- & --- & --- & --- & $\begin{array}{l}-0.014 \\
(0.015)\end{array}$ \\
\hline Age $50-61 *$ Year 2004-2007 & --- & --- & --- & --- & $\begin{array}{l}-0.016 \\
(0.017)\end{array}$ \\
\hline Age $62+*$ Year 2004-2007 & --- & --- & --- & --- & $\begin{array}{l}0.010 \\
(0.029)\end{array}$ \\
\hline $\begin{array}{l}\text { Occupation and industry } \\
\text { controls }\end{array}$ & No & No & Yes & Yes & Yes \\
\hline $\mathrm{N}$ & $1,702,822$ & $1,702,822$ & $1,702,822$ & $1,702,822$ & $1,702,822$ \\
\hline Pseudo r-squared & 0.00412 & 0.0153 & 0.0329 & 0.0420 & 0.0421 \\
\hline Mean of dependent variable (times 100 ) & 0.199 & 0.199 & 0.199 & 0.199 & 0.199 \\
\hline
\end{tabular}

Source: Authors' tabulations from the 1996, 2001, and 2004 SIPP panels, spanning the years 1996-2007.

Notes: Cell entries show the percentage point impact of each variable on the likelihood of losing one's job because of layoff, slack work, or employer bankruptcy, or because the employer sold the business, based on discrete-time hazard models. Standard errors are in parentheses. Models are estimated as logits. All financial amounts are measured in constant 2009 dollars.

$* * p<.05 ; * .10>p>.05$ 
Table 4. Characteris tics of Reemployment Sample

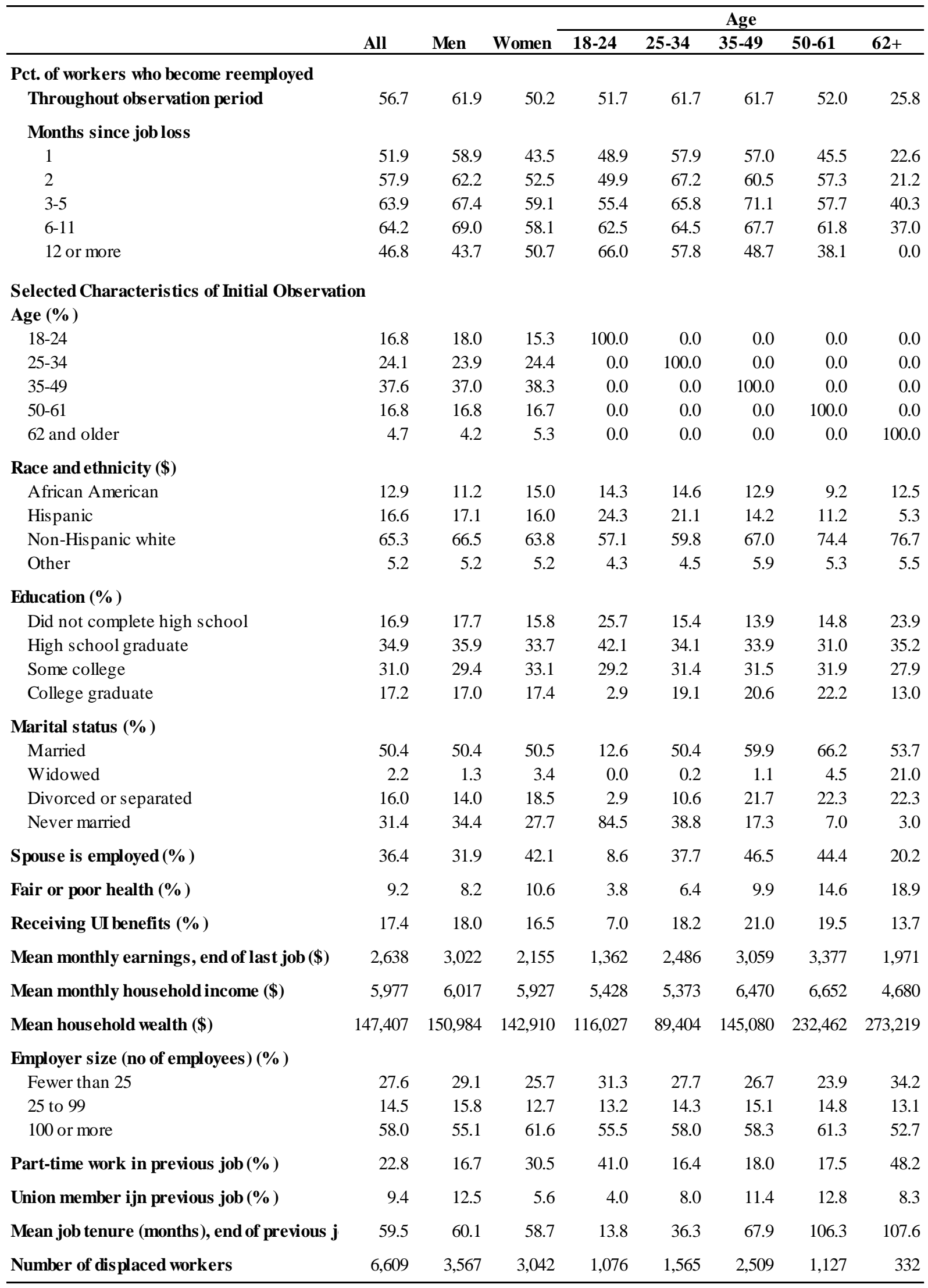

Source: Authors' estimates from 1996, 2001,and 2004 SIPP panels, spanning the years 1996 to 2007

Note: The sample is restricted to workers age 18 and older who were displaced from a wage and salary job. Financial amounts are measured in constant 2009 dollars. 
Table 5. Marginal Impact on the Likelihood of Becoming Reemployed, for Displaced Male Wage and Salary Workers Age 18 and Older

\begin{tabular}{|c|c|c|c|c|}
\hline & (1) & (2) & (3) & (4) \\
\hline \multicolumn{5}{|l|}{ Age } \\
\hline $18-24$ & $\begin{array}{l}-0.004 \\
(0.012)\end{array}$ & $\begin{array}{l}-0.007 \\
(0.012)\end{array}$ & $\begin{array}{l}-0.010 \\
(0.012)\end{array}$ & $\begin{array}{l}-0.003 \\
(0.013)\end{array}$ \\
\hline [Reference: 25-34] & --- & --- & --- & --- \\
\hline $35-49$ & $\begin{array}{l}-0.027^{* *} \\
(0.009)\end{array}$ & $\begin{array}{l}-0.023^{* *} \\
(0.009)\end{array}$ & $\begin{array}{l}-0.019^{* *} \\
(0.010)\end{array}$ & $\begin{array}{l}-0.020^{* *} \\
(0.010)\end{array}$ \\
\hline $50-61$ & $\begin{array}{l}-0.086^{* *} \\
(0.009)\end{array}$ & $\begin{array}{l}-0.080 * * \\
(0.010)\end{array}$ & $\begin{array}{l}-0.077 * * \\
(0.010)\end{array}$ & $\begin{array}{l}-0.077 * * \\
(0.010)\end{array}$ \\
\hline 62 and older & $\begin{array}{l}-0.104 * * \\
(0.014)\end{array}$ & $\begin{array}{l}-0.100 * * \\
(0.014)\end{array}$ & $\begin{array}{l}-0.100^{* *} \\
(0.014)\end{array}$ & $\begin{array}{l}-0.100^{* *} \\
(0.014)\end{array}$ \\
\hline \multicolumn{5}{|l|}{ Race and ethnicity } \\
\hline African American & , $^{--}$ & ,-- & $\begin{array}{l}-0.067^{* *} \\
(0.010)\end{array}$ & $\begin{array}{l}-0.064 * * \\
(0.010)\end{array}$ \\
\hline Hispanic & ,-- & ,--- & $\begin{array}{l}-0.050^{* *} \\
(0.010)\end{array}$ & $\begin{array}{l}-0.050^{* *} \\
(0.010)\end{array}$ \\
\hline [Reference: Non-Hispanic white] & --- & --- & --- & --- \\
\hline Other race & --- & --- & $\begin{array}{l}-0.039 * * \\
(0.014)\end{array}$ & $\begin{array}{l}-0.039 * * \\
(0.014)\end{array}$ \\
\hline \multicolumn{5}{|l|}{ Education } \\
\hline Not high school graduate & $r^{---}$ & ,--- & $\begin{array}{l}-0.008 \\
(0.011)\end{array}$ & $\begin{array}{l}-0.007 \\
(0.011)\end{array}$ \\
\hline [Reference: high school graduate] & --- & --- & --- & --- \\
\hline Some college & $r^{---}$ & , --- & $\begin{array}{l}0.014 \\
(0.009)\end{array}$ & $\begin{array}{l}0.015 \\
(0.010)\end{array}$ \\
\hline Four or more years of college & --- & --- & $\begin{array}{l}0.004 \\
(0.012)\end{array}$ & $\begin{array}{l}0.007 \\
(0.014)\end{array}$ \\
\hline \multicolumn{5}{|l|}{ Marital Status } \\
\hline [Reference: Married] & --- & --- & --- & --- \\
\hline Widowed & ,-- & ,--- & $\begin{array}{l}0.002 \\
(0.037)\end{array}$ & $\begin{array}{l}0.007 \\
(0.037)\end{array}$ \\
\hline Divorced or separated & ,-- & , --- & $\begin{array}{l}-0.028 * * \\
(0.012)\end{array}$ & $\begin{array}{l}-0.025^{* *} \\
(0.012)\end{array}$ \\
\hline Never married & ,-- & ,--- & $\begin{array}{l}-0.036^{* *} \\
(0.011)\end{array}$ & $\begin{array}{l}-0.031 * * \\
(0.011)\end{array}$ \\
\hline Spouse is employed & --- & --- & $\begin{array}{l}0.004 \\
(0.011)\end{array}$ & $\begin{array}{l}0.006 \\
(0.011)\end{array}$ \\
\hline
\end{tabular}

(continued) 
Table 5 (continued).

\section{Region}

Northeast

[Reference: Midwest]

South

West

Fair or poor health

Months since job loss

Receiving unemployment insurance benefits

Natural log of household income

Natural log of household wealth

Indicator for negative household wealth

Natural log of earnings last month employed

Employer size (no. of employees)

Fewer than 25

25 to 99

[Reference: 100 or more]

Part-time work

Union member

Job tenure in months, end of last job
(1)

(2)

(3)

(4)

$\begin{array}{llll}--- & -0.016 & -0.018^{*} \\ & & (0.011) & (0.011)\end{array}$

$\begin{array}{lllll}--- & -- & -- & -\end{array}$

$\begin{array}{llll}--- & & 0.008 & 0.008\end{array}$

(0.010) $\quad(0.010)$

-

$(0.011) \quad(0.012)$

$-0.043 * *-0.041 * *$

$(0.012) \quad(0.012)$

$-0.011^{* *} \quad-0.011^{* *}$

$(0.001) \quad(0.001)$

$-0.076^{* *} \quad-0.075^{* *}$

$(0.008) \quad(0.008)$

$-0.002 \quad-0.002$

$(0.002) \quad(0.002)$

$0.002 \quad 0.002$

$(0.002) \quad(0.002)$

$0.050^{*} \quad 0.050^{*}$

$(0.030) \quad(0.030)$

$---\quad 0.001$

(0.003)

--
--

(0.009)

,-- , ,-- ,

$(0.011)$

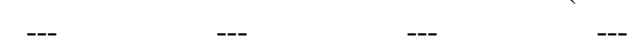

, $^{--} \quad$, $^{--} \quad$,-- $\quad-0.011$

$(0.011)$

0.010

(0.012)

0.00001

$(0.0001)$ 
Table 5 (continued).

\begin{tabular}{|c|c|c|c|c|}
\hline & (1) & (2) & (3) & (4) \\
\hline \multicolumn{5}{|l|}{ Year } \\
\hline [Reference: 1996] & --- & --- & --- & --- \\
\hline 1997 & , $^{---}$ & $\begin{array}{l}-0.013 \\
(0.015)\end{array}$ & $\begin{array}{l}0.004 \\
(0.015)\end{array}$ & $\begin{array}{l}0.004 \\
(0.015)\end{array}$ \\
\hline 1998 & r $^{---}$ & $\begin{array}{l}-0.008 \\
(0.018)\end{array}$ & $\begin{array}{l}0.013 \\
(0.019)\end{array}$ & $\begin{array}{l}0.015 \\
(0.019)\end{array}$ \\
\hline 1999 & , -- & $\begin{array}{l}-0.054 * * \\
(0.017)\end{array}$ & $\begin{array}{l}-0.035^{*} \\
(0.018)\end{array}$ & $\begin{array}{l}{ }^{-}-0.033^{*} \\
(0.019)\end{array}$ \\
\hline 2000 & , $^{---}$ & $\begin{array}{l}-0.066^{*} \\
(0.039)\end{array}$ & $\begin{array}{l}-0.057 \\
(0.040)\end{array}$ & $\begin{array}{l}-0.057 \\
(0.040)\end{array}$ \\
\hline 2001 & ,-- & $\begin{array}{l}-0.022^{*} \\
(0.013)\end{array}$ & $\begin{array}{l}-0.021 \\
(0.013)\end{array}$ & $\begin{array}{l}-0.019 \\
(0.013)\end{array}$ \\
\hline 2002 & ${ }^{---}$ & $\begin{array}{l}-0.074 * * \\
(0.011)\end{array}$ & $\begin{array}{l}-0.049 * * \\
(0.012)\end{array}$ & $\begin{array}{l}-0.050 * * \\
(0.012)\end{array}$ \\
\hline 2003 & ,-- & $\begin{array}{l}-0.087 * * \\
(0.012)\end{array}$ & $\begin{array}{l}-0.057 * * \\
(0.013)\end{array}$ & $\begin{array}{l}-0.057 * * \\
(0.013)\end{array}$ \\
\hline 2004 & ,-- & $\begin{array}{l}-0.034 * * \\
(0.013)\end{array}$ & $\begin{array}{l}-0.037 * * \\
(0.013)\end{array}$ & $\begin{array}{l}-0.045^{* *} \\
(0.013)\end{array}$ \\
\hline 2005 & ,-- & $\begin{array}{l}-0.058^{* *} \\
(0.012)\end{array}$ & $\begin{array}{l}-0.044 * * \\
(0.013)\end{array}$ & $\begin{array}{l}-0.051^{* *} \\
(0.013)\end{array}$ \\
\hline 2006 & ,--- & $\begin{array}{l}-0.054^{* *} \\
(0.015)\end{array}$ & $\begin{array}{l}-0.023 \\
(0.017)\end{array}$ & $\begin{array}{l}-0.031^{*} \\
(0.017)\end{array}$ \\
\hline 2007 & --- & $\begin{array}{l}-0.056^{* *} \\
(0.023)\end{array}$ & $\begin{array}{l}-0.023 \\
(0.027)\end{array}$ & $\begin{array}{l}-0.027 \\
(0.026)\end{array}$ \\
\hline Occupation and industry controls & No & No & No & Yes \\
\hline $\mathrm{N}$ & 11231 & 11231 & 11231 & 11230 \\
\hline Pseudo R-squared & 0.0090 & 0.0159 & 0.0445 & 0.0475 \\
\hline Mean of dependent variable & 0.198 & 0.198 & 0.198 & 0.198 \\
\hline
\end{tabular}

Source: Authors' tabulations from the 1996, 2001, and 2004 SIPP panels, spanning the years 1996-2007.

Notes: Cell entries show the impact of each variable on the likelihood of becoming reemployed, based on discretetime hazard models. Models are estimated as logits. All financial amounts are measured in constant 2009 dollars.

$* * p<.05 ; * .10>p>.05$; 
Table 6. Marginal Impact on the Likelihood of Becoming Reemployed, for Displaced Female Wage and Salary Workers Age 18 and Older

\begin{tabular}{|c|c|c|c|c|}
\hline & (1) & (2) & (3) & (4) \\
\hline \multicolumn{5}{|l|}{ Age } \\
\hline $18-24$ & $\begin{array}{l}0.031^{* *} \\
(0.014)\end{array}$ & $\begin{array}{l}0.029^{* *} \\
(0.014)\end{array}$ & $\begin{array}{l}0.003 \\
(0.013)\end{array}$ & $\begin{array}{l}0.0004 \\
(0.013)\end{array}$ \\
\hline [Reference: 25-34] & --- & --- & --- & --- \\
\hline $35-49$ & $\begin{array}{l}-0.015 \\
(0.009)\end{array}$ & $\begin{array}{l}-0.013 \\
(0.009)\end{array}$ & $\begin{array}{l}-0.009 \\
(0.009)\end{array}$ & $\begin{array}{l}-0.004 \\
(0.010)\end{array}$ \\
\hline $50-61$ & $\begin{array}{l}-0.037 * * \\
(0.010)\end{array}$ & $\begin{array}{l}-0.037 * * \\
(0.010)\end{array}$ & $\begin{array}{l}-0.033^{* *} \\
(0.011)\end{array}$ & $\begin{array}{l}-0.028^{* * *} \\
(0.011)\end{array}$ \\
\hline 62 and older & $\begin{array}{l}-0.094 * * \\
(0.012)\end{array}$ & $\begin{array}{l}-0.091 * * \\
(0.013)\end{array}$ & $\begin{array}{l}-0.088^{* *} \\
(0.012)\end{array}$ & $\begin{array}{l}-0.080 * * \\
(0.014)\end{array}$ \\
\hline \multicolumn{5}{|l|}{ Race and ethnicity } \\
\hline African American & --- & --- & $\begin{array}{l}-0.048^{* *} \\
(0.009)\end{array}$ & $\begin{array}{l}-0.051 * * \\
(0.009)\end{array}$ \\
\hline Hispanic & --- & --- & $\begin{array}{l}-0.047 * * \\
(0.010)\end{array}$ & $\begin{array}{l}-0.042 * * \\
(0.010)\end{array}$ \\
\hline [Reference: Non-His panic white] & --- & --- & --- & --- \\
\hline Other race & --- & --- & $\begin{array}{l}-0.025^{*} \\
(0.014)\end{array}$ & $\begin{array}{l}-0.025^{*} \\
(0.014)\end{array}$ \\
\hline \multicolumn{5}{|l|}{ Education } \\
\hline Not high school graduate & --- & --- & $\begin{array}{l}-0.017 \\
(0.011)\end{array}$ & $\begin{array}{l}-0.016 \\
(0.011)\end{array}$ \\
\hline [Reference: high school graduate] & --- & --- & --- & --- \\
\hline Some college & --- & --- & $\begin{array}{l}0.006 \\
(0.009)\end{array}$ & $\begin{array}{l}-0.003 \\
(0.009)\end{array}$ \\
\hline Four or more years of college & --- & --- & $\begin{array}{l}0.006 \\
(0.011)\end{array}$ & $\begin{array}{l}-0.008 \\
(0.012)\end{array}$ \\
\hline \multicolumn{5}{|l|}{ Marital Status } \\
\hline [Reference: Married] & --- & --- & --- & --- \\
\hline Widowed & --- & --- & $\begin{array}{l}0.051 \\
(0.032)\end{array}$ & $\begin{array}{l}0.043 \\
(0.031)\end{array}$ \\
\hline Divorced or separated & --- & --- & $\begin{array}{l}0.046^{* *} \\
(0.018)\end{array}$ & $\begin{array}{l}0.039 * * \\
(0.017)\end{array}$ \\
\hline Never married & --- & --- & $\begin{array}{l}0.041^{* *} \\
(0.018)\end{array}$ & $\begin{array}{l}0.037 * * \\
(0.018)\end{array}$ \\
\hline Spouse is employed & --- & --- & $\begin{array}{l}0.017 \\
(0.015)\end{array}$ & $\begin{array}{l}0.013 \\
(0.015)\end{array}$ \\
\hline
\end{tabular}

(continued) 
Table 6 (continued).

\begin{tabular}{|c|c|c|c|c|}
\hline & (1) & (2) & (3) & (4) \\
\hline \multicolumn{5}{|l|}{ Region } \\
\hline Northeast & --- & --- & $\begin{array}{l}0.007 \\
(0.011)\end{array}$ & $\begin{array}{l}0.006 \\
(0.011)\end{array}$ \\
\hline [Reference: Midwest] & --- & --- & --- & --- \\
\hline South & --- & --- & $\begin{array}{l}0.009 \\
(0.010)\end{array}$ & $\begin{array}{l}0.009 \\
(0.010)\end{array}$ \\
\hline West & --- & --- & $\begin{array}{l}0.004 \\
(0.011)\end{array}$ & $\begin{array}{l}0.0004 \\
(0.011)\end{array}$ \\
\hline Fair or poor health & --- & --- & $\begin{array}{l}-0.024 * * \\
(0.011)\end{array}$ & $\begin{array}{l}-0.022^{* *} \\
(0.011)\end{array}$ \\
\hline Months since job loss & --- & --- & $\begin{array}{l}-0.006^{* *} \\
(0.001)\end{array}$ & $\begin{array}{l}-0.006^{* *} \\
(0.001)\end{array}$ \\
\hline Receiving unemployment insurance benefits & --- & --- & $\begin{array}{l}-0.068 * * \\
(0.007)\end{array}$ & $\begin{array}{l}-0.069 * * \\
(0.007)\end{array}$ \\
\hline Natural log of household income & --- & --- & $\begin{array}{l}0.001 \\
(0.002)\end{array}$ & $\begin{array}{l}0.001 \\
(0.002)\end{array}$ \\
\hline Natural log of household wealth & --- & --- & $\begin{array}{l}-0.001 \\
(0.002)\end{array}$ & $\begin{array}{l}-0.002 \\
(0.002)\end{array}$ \\
\hline Indicator for negative household wealth & --- & --- & $\begin{array}{l}-0.029 \\
(0.024)\end{array}$ & $\begin{array}{l}-0.033 \\
(0.023)\end{array}$ \\
\hline Natural log of earnings last month employed & --- & --- & --- & $\begin{array}{l}0.004 \\
(0.003)\end{array}$ \\
\hline \multicolumn{5}{|l|}{ Employer size (no. of employees) } \\
\hline Fewer than 25 & --- & --- & --- & $\begin{array}{l}0.008 \\
(0.009)\end{array}$ \\
\hline 25 to 99 & --- & --- & --- & $\begin{array}{l}-0.011 \\
(0.011)\end{array}$ \\
\hline [Reference: 100 or more] & --- & --- & --- & --- \\
\hline Part-time work & --- & --- & --- & $\begin{array}{l}-0.012 \\
(0.009)\end{array}$ \\
\hline Union member & --- & --- & --- & $\begin{array}{l}0.038^{* *} \\
(0.019)\end{array}$ \\
\hline Job tenure in months, end of last job & --- & --- & --- & $\begin{array}{l}-0.0001^{* *} \\
(0.000)\end{array}$ \\
\hline
\end{tabular}

(continued) 
Table 6 (continued).

\begin{tabular}{|c|c|c|c|c|}
\hline & (1) & (2) & (3) & (4) \\
\hline \multicolumn{5}{|l|}{ Year } \\
\hline \multicolumn{5}{|l|}{ [Reference: 1996] } \\
\hline 1997 & --- & $\begin{array}{l}0.006 \\
(0.015)\end{array}$ & $\begin{array}{l}0.011 \\
(0.015)\end{array}$ & $\begin{array}{l}0.013 \\
(0.015)\end{array}$ \\
\hline 1998 & --- & $\begin{array}{l}-0.011 \\
(0.017)\end{array}$ & $\begin{array}{l}0.004 \\
(0.018)\end{array}$ & $\begin{array}{l}0.011 \\
(0.018)\end{array}$ \\
\hline 1999 & --- & $\begin{array}{l}-0.009 \\
(0.020)\end{array}$ & $\begin{array}{l}0.010 \\
(0.021)\end{array}$ & $\begin{array}{l}0.009 \\
(0.021)\end{array}$ \\
\hline 2000 & --- & $\begin{array}{l}-0.138^{* *} \\
(0.018)\end{array}$ & $\begin{array}{l}-0.131 * * \\
(0.017)\end{array}$ & $\begin{array}{l}-0.130 * * \\
(0.016)\end{array}$ \\
\hline 2001 & --- & $\begin{array}{l}-0.017 \\
(0.013)\end{array}$ & $\begin{array}{l}-0.014 \\
(0.013)\end{array}$ & $\begin{array}{l}-0.016 \\
(0.013)\end{array}$ \\
\hline 2002 & --- & $\begin{array}{l}-0.060 * * \\
(0.011)\end{array}$ & $\begin{array}{l}-0.037 * * \\
(0.012)\end{array}$ & $\begin{array}{l}-0.039 * * \\
(0.012)\end{array}$ \\
\hline 2003 & --- & $\begin{array}{l}-0.054 * * \\
(0.013)\end{array}$ & $\begin{array}{l}-0.027^{*} \\
(0.015)\end{array}$ & $\begin{array}{l}-0.027^{*} \\
(0.015)\end{array}$ \\
\hline 2004 & --- & $\begin{array}{l}{ }^{5}-0.045^{* *} \\
(0.013)\end{array}$ & $\begin{array}{l}-0.048^{* *} \\
(0.012)\end{array}$ & $\begin{array}{l}-0.046^{* *} \\
(0.013)\end{array}$ \\
\hline 2005 & --- & $\begin{array}{l}-0.014 \\
(0.014)\end{array}$ & $\begin{array}{l}-0.004 \\
(0.014)\end{array}$ & $\begin{array}{l}-0.004 \\
-(0.015)\end{array}$ \\
\hline 2006 & --- & $\begin{array}{l}-0.022 \\
(0.017)\end{array}$ & $\begin{array}{l}-0.005 \\
(0.019)\end{array}$ & $\begin{array}{l}-0.004 \\
(0.020)\end{array}$ \\
\hline 2007 & --- & $\begin{array}{l}-0.049 * * \\
(0.021)\end{array}$ & $\begin{array}{l}-0.028 \\
(0.024)\end{array}$ & $\begin{array}{l}-0.027 \\
(0.024)\end{array}$ \\
\hline Occupation and industry controls & No & No & No & Yes \\
\hline $\mathrm{N}$ & 9,517 & 9517 & 9517 & 9517 \\
\hline Pseudo R-squared & 0.0070 & 0.0140 & 0.0400 & 0.0456 \\
\hline Mean of dependent variable & 0.159 & 0.159 & 0.159 & 0.159 \\
\hline
\end{tabular}

Source: Authors' tabulations from the 1996, 2001, and 2004 SIPP panels, spanning the years 1996-2007.

Notes: Cell entries show the impact of each variable on the likelihood of becoming reemployed, based on discretetime hazard models. Models are estimated as logits. All financial amounts are measured in constant 2009 dollars. $* * p<.05 ; \quad * .10>p>.05 ;$ 
Table 7. Percentage of Reemployed Displaced Wage and Salary Workers Who Change Occupation or Industry, by Age and Sex

\begin{tabular}{llllr}
\hline Sex & Age & $\begin{array}{c}\text { New } \\
\text { Occupation }\end{array}$ & $\begin{array}{c}\text { New } \\
\text { Industry }\end{array}$ & $\begin{array}{c}\text { No. of } \\
\text { Obs. }\end{array}$ \\
\hline \multirow{4}{*}{ Men } & & & & \\
& & & & \\
& $\mathbf{1 8 - 2 4}$ & $60.2 * *$ & $63.5 * *$ & 518 \\
& $\mathbf{2 5 - 3 4}$ & 49.9 & 49.5 & 695 \\
& $\mathbf{3 5 - 4 9}$ & 47.6 & 50.4 & 1061 \\
& $\mathbf{5 0 - 6 1}$ & 49.0 & 54.0 & 444 \\
& $\mathbf{6 2 +}$ & 46.9 & 41.0 & 87 \\
& & & & \\
Women & & & & \\
& $\mathbf{1 8 - 2 4}$ & $61.5 *$ & 47.9 & 330 \\
& $\mathbf{2 5 - 3 4}$ & 54.7 & 52.3 & 567 \\
& $\mathbf{3 5 - 4 9}$ & $48.1 * *$ & $44.4 * *$ & 855 \\
& $\mathbf{5 0 - 6 1}$ & 52.5 & $45.6 *$ & 358 \\
& $\mathbf{6 2 +}$ & $37.9 * *$ & $36.6 * *$ & 67 \\
\hline
\end{tabular}

Source: Authors' computations from the 1996, 2001, and 2004 SIPP panels, spanning the years 1996 to 2007.

Note: The sample is restricted to wage and salary workers age 18 and older displaced from their jobs because of layoff, slack work, or employer bankruptcy, or because the employer sold the business, who become reemployed during the observation period. Asterisks indicate that the value differs significantly from that for workers age 25 to 34 $(* * \mathrm{p}<.05 ; * .10>\mathrm{p}>.05)$.

Table 8. Percentage of Reemployed Displaced Wage and Salary Workers Who Are Self-Employed on the New Job, by Age and Sex

\begin{tabular}{llcc}
\hline Age & All & Men & Women \\
\hline $\mathbf{1 8 - 2 4}$ & $2.2 * *$ & 2.9 & $1.0 * *$ \\
$\mathbf{2 5 - 3 4}$ & 4.0 & 3.8 & 4.3 \\
$\mathbf{3 5 - 4 9}$ & 4.3 & 5.1 & 3.3 \\
$\mathbf{5 0 - 6 1}$ & 5.0 & 6.0 & 3.6 \\
$\mathbf{6 2}$ and older & $0.3 * *$ & $0.0 * *$ & $1.0 * *$ \\
\hline
\end{tabular}

Source: Authors' computations from the 1996, 2001, and 2004 SIPP panels, spanning the years 1996 to 2007.

Note: The sample is restricted to wage and salary workers age 18 and older displaced from their jobs because of layoff, slack work, or employer bankruptcy, or because the employer sold the business, who become reemployed during the observation period. Asterisks indicate that the value differs significantly from that for workers age 25 to $34(* * p<.05$; $* .10>p>.05$ ). 
Table 9. Mean Weekly Hours on the New and Old Job for Reemployed Displaced Workers, by Age and Full-Time Status on Old Job

\begin{tabular}{lllll}
\hline $\begin{array}{l}\text { Status on } \\
\text { old job }\end{array}$ & Age & Old job & New job & Change \\
\hline Full-time & & & & \\
& $\mathbf{1 8 - 2 4}$ & $41.2 * *$ & $40.3 * *$ & $-0.9 * *$ \\
& $\mathbf{2 5 - 3 4}$ & 42.4 & 42.0 & $-0.4 * *$ \\
& $\mathbf{3 5 - 4 9}$ & $43.1 * *$ & $42.8 * *$ & $-0.3 * *$ \\
& $\mathbf{5 0 - 6 1}$ & $43.0 *$ & $42.8 * *$ & -0.2 \\
& $\mathbf{6 2 +}$ & 42.0 & 40.9 & -1.1 \\
& & & & \\
Part-time & & 21.7 & $22.9 * *$ & $1.2 * *$ \\
& $\mathbf{1 8 - 2 4}$ & 22.5 & 25.1 & $2.6 * *$ \\
& $\mathbf{2 5 - 3 4}$ & 23.0 & 25.3 & $2.3 * *$ \\
& $\mathbf{3 5 - 4 9}$ & 23.8 & 26.2 & $2.4 * *$ \\
& $\mathbf{5 0 - 6 1}$ & $18.4 * *$ & $20.6 * *$ & $2.2 * *$ \\
& $\mathbf{6 2 +}$ & & & \\
\hline
\end{tabular}

Source: Authors' computations from the 1996, 2001, and 2004 SIPP panels, spanning the years 1996 to 2007.

Note: Part-time employment is defined as fewer than 35 hours of employment per week. The sample is restricted to wage and salary workers age 18 and older displaced from their jobs because of layoff, slack work, or employer bankruptcy, or because the employer sold the business, who become reemployed during the observation period. Asterisks on mean hours values indicate that they differ significantly from that for workers age 25 to 34 . Asterisks on the change values indicate that they differ significantly from zero $(* * p<.05 ; * .10>p>.05)$. 
Table 10. Median Hourly Wage on the New and Old Job and Change in Hourly Wage for Displaced Wage and Salary Workers Who Become Reemployed

\begin{tabular}{|c|c|c|c|c|c|c|c|c|}
\hline \multirow[b]{2}{*}{ Sex } & \multirow[b]{2}{*}{ Age } & \multicolumn{4}{|c|}{ Median Hourly Wage (\$) } & \multicolumn{2}{|c|}{ Pct. of Workers Earning: } & \multirow[b]{2}{*}{$\begin{array}{r}\text { Number } \\
\text { of obs. }\end{array}$} \\
\hline & & Old job & New job & Difference & $\begin{array}{c}\text { Percentage } \\
\text { Change }\end{array}$ & $\begin{array}{c}\text { At least } 10 \% \\
\text { more on new } \\
\text { job } \\
\end{array}$ & $\begin{array}{c}\text { At least } 10 \% \\
\text { less on new } \\
\text { job } \\
\end{array}$ & \\
\hline \multicolumn{9}{|l|}{ Men } \\
\hline & $18-24$ & $9.3 * *$ & $9.5 * *$ & 0.2 & 2.2 & 40.4 & 45.3 & 518 \\
\hline & $50-61$ & $18.9 * *$ & $15.1 * *$ & $-3.8 * *$ & -20.1 & $28.0 * *$ & $53.9 * *$ & 444 \\
\hline & $62+$ & 16.0 & 10.3 & $-5.7 * *$ & -35.6 & $25.2 * *$ & $63.0 * *$ & 87 \\
\hline \multicolumn{9}{|c|}{ Women } \\
\hline & $18-24$ & $8.1 * *$ & $8.6 * *$ & $0.5 * *$ & 6.8 & $41.7 * *$ & 47.7 & 330 \\
\hline
\end{tabular}

Source: Authors' computations from the 1996, 2001, and 2004 SIPP panels, spanning the years 1996 to 2007.

Note: The sample is restricted to wage and salary workers age 18 and older displaced from their jobs because of layoff, slack work, or employer bankruptcy, or because the employer sold the business, who become reemployed during the observation period. Wages are measured in constant 2009 dollars. Asterisks indicate that the value differs significantly from that for workers age 25 to 34 $(* * \mathrm{p}<.05 ; * .10>\mathrm{p}>.05)$.

Table 11. Median Monthly Earnings on the New and Old Job and Change in Monthly Earnings for Displaced Wage and Salary Workers Who Become Reemployed

\begin{tabular}{|c|c|c|c|c|c|c|c|c|}
\hline \multirow[b]{2}{*}{$\underline{\operatorname{Sex}}$} & \multirow[b]{2}{*}{ Age } & \multicolumn{4}{|c|}{ Median Monthly Earnings (\$) } & \multicolumn{2}{|c|}{ Pct. of Workers Earning: } & \multirow[b]{2}{*}{$\begin{array}{c}\text { Number } \\
\text { of obs. }\end{array}$} \\
\hline & & Old job & New job & Difference & $\begin{array}{c}\text { Percentage } \\
\text { Change }\end{array}$ & $\begin{array}{c}\text { more on new } \\
\text { job } \\
\end{array}$ & $\begin{array}{c}\text { At least } 10 \% \\
\text { less on new job }\end{array}$ & \\
\hline \multicolumn{9}{|l|}{ Men } \\
\hline & $18-24$ & $1337 * *$ & $1367 * *$ & 30 & 2.2 & 40.3 & 45.9 & 518 \\
\hline & 25-34 & 2139 & 2074 & -65 & -3.0 & 38.9 & 42.8 & 695 \\
\hline & $35-49$ & $2862 * *$ & $2632 * *$ & $-230 *$ & -8.0 & 36.3 & 43.7 & 1061 \\
\hline & $50-61$ & $3159 * *$ & $2509 * *$ & $-650 * *$ & -20.6 & $27.3 * *$ & $53.3 * *$ & 444 \\
\hline & $62+$ & 1908 & 1336 & $-572 * *$ & -30.0 & $25.9 * *$ & $62.4 * *$ & 87 \\
\hline \multicolumn{9}{|c|}{ Women } \\
\hline & $18-24$ & $984 * *$ & $1066 * *$ & 82 & 8.3 & $43.7 * *$ & 46.8 & 330 \\
\hline & $25-34$ & 2021 & 1474 & $-547 * *$ & -27.1 & 32.0 & 51.7 & 567 \\
\hline & $35-49$ & 1903 & $1603 *$ & $-300 * *$ & -15.8 & 31.2 & 50.1 & 855 \\
\hline & $50-61$ & 1886 & 1562 & $-324 * *$ & -17.2 & 31.8 & 51.8 & 358 \\
\hline & $62+$ & $1135 * *$ & $852 * *$ & $-283 * *$ & -24.9 & 28.2 & 54.1 & 67 \\
\hline
\end{tabular}

Source: Urban Institute computations from the 1996, 2001, and 2004 SIPP panels, spanning the years 1996 to 2007.

Note: The sample is restricted to wage and salary workers age 18 and older displaced from their jobs because of layoff, slack work, or employer bankruptcy, or because the employer sold the business, who become reemployed during the observation period. Earnings are measured in constant 2009 dollars. Asterisks indicate that the value differs significantly from that for workers age 25 to 34 $(* * \mathrm{p}<.05 ; * .10>\mathrm{p}>.05)$. 
Table 12. OLS Regressions of Change in Hourly Earnings for Displaced Male Wage and Salary Workers who Become Reemployed

\begin{tabular}{|c|c|c|c|c|}
\hline & (1) & (2) & (3) & (4) \\
\hline \multicolumn{5}{|l|}{ Age } \\
\hline $18-24$ & $\begin{array}{l}0.952 \\
(0.789)\end{array}$ & $\begin{array}{l}-0.692 \\
(0.869)\end{array}$ & $\begin{array}{l}-0.727 \\
(0.872)\end{array}$ & $\begin{array}{l}-0.617 \\
(0.874)\end{array}$ \\
\hline [Reference: 25-34] & --- & --- & --- & --- \\
\hline $35-49$ & $\begin{array}{l}-0.573 \\
(0.657)\end{array}$ & $\begin{array}{l}0.359 \\
(0.683)\end{array}$ & $\begin{array}{l}0.357 \\
(0.687)\end{array}$ & $\begin{array}{l}0.355 \\
(0.687)\end{array}$ \\
\hline $50-61$ & $\begin{array}{l}-3.937 * * \\
(0.819)\end{array}$ & $\begin{array}{l}-2.356^{* *} \\
(0.889)\end{array}$ & $\begin{array}{l}-2.406^{* *} \\
(0.898)\end{array}$ & $\begin{array}{l}-2.382 * * \\
(0.898)\end{array}$ \\
\hline 62 and older & $\begin{array}{l}-4.058^{* *} \\
(1.510)\end{array}$ & $\begin{array}{l}-4.339^{* *} \\
(1.588)\end{array}$ & $\begin{array}{l}-4.434 * * \\
(1.605)\end{array}$ & $\begin{array}{l}-4.544 * * \\
(1.605)\end{array}$ \\
\hline \multicolumn{5}{|l|}{ Race and ethnicity } \\
\hline African American & --- & $\begin{array}{l}0.642 \\
(0.870)\end{array}$ & $\begin{array}{l}0.612 \\
(0.878)\end{array}$ & $\begin{array}{l}0.671 \\
(0.879)\end{array}$ \\
\hline Hispanic & --- & $\begin{array}{l}1.300^{*} \\
(0.779)\end{array}$ & $\begin{array}{l}1.325^{*} \\
(0.786)\end{array}$ & $\begin{array}{l}1.301^{*} \\
(0.786)\end{array}$ \\
\hline [Reference: Non-Hispanic white] & --- & --- & --- & --- \\
\hline Other & --- & $\begin{array}{l}-0.558 \\
(1.151)\end{array}$ & $\begin{array}{l}-0.542 \\
(1.153)\end{array}$ & $\begin{array}{l}-0.572 \\
(1.153)\end{array}$ \\
\hline \multicolumn{5}{|l|}{ Education } \\
\hline Not high school graduate & --- & $\begin{array}{l}-0.0155 \\
(0.775)\end{array}$ & $\begin{array}{l}0.0150 \\
(0.777)\end{array}$ & $\begin{array}{l}-0.0164 \\
(0.777)\end{array}$ \\
\hline [Reference: High school graduate] & --- & -- & --- & --- \\
\hline Some college & --- & $\begin{array}{l}-1.074 * \\
(0.627)\end{array}$ & $\begin{array}{l}-1.111^{*} \\
(0.629)\end{array}$ & $\begin{array}{l}-1.093^{*} \\
(0.629)\end{array}$ \\
\hline Four or more years of college & --- & $\begin{array}{l}-2.193^{* *} \\
(0.798)\end{array}$ & $\begin{array}{l}-2.296 * * \\
(0.820)\end{array}$ & $\begin{array}{l}-2.291 \text { ** } \\
(0.821)\end{array}$ \\
\hline \multicolumn{5}{|l|}{ Marital status } \\
\hline [Reference: Married] & --- & --- & --- & --- \\
\hline Divorced or separated & --- & $\begin{array}{l}0.310 \\
(0.926)\end{array}$ & $\begin{array}{l}0.337 \\
(0.928)\end{array}$ & $\begin{array}{l}0.390 \\
(0.928)\end{array}$ \\
\hline Widowed & --- & $\begin{array}{l}1.484 \\
(2.442)\end{array}$ & $\begin{array}{l}1.531 \\
(2.443)\end{array}$ & $\begin{array}{l}1.581 \\
(2.443)\end{array}$ \\
\hline Never married & --- & $\begin{array}{l}0.778 \\
(0.826)\end{array}$ & $\begin{array}{l}0.776 \\
(0.826)\end{array}$ & $\begin{array}{l}0.787 \\
(0.826)\end{array}$ \\
\hline Spouse employed & --- & $\begin{array}{l}1.155 \\
(0.732)\end{array}$ & $\begin{array}{l}1.153 \\
(0.733)\end{array}$ & $\begin{array}{l}1.178 \\
(0.733)\end{array}$ \\
\hline \multicolumn{5}{|l|}{ Health Status } \\
\hline Fair or poor on new job, better on old job & --- & $\begin{array}{l}-3.012 \\
(2.105)\end{array}$ & $\begin{array}{l}-3.059 \\
(2.106)\end{array}$ & $\begin{array}{l}-3.058 \\
(2.105)\end{array}$ \\
\hline Excellent, very good, or good on new job, worse on old job & --- & $\begin{array}{l}1.383 \\
(1.936)\end{array}$ & $\begin{array}{l}1.380 \\
(1.936)\end{array}$ & $\begin{array}{l}1.432 \\
(1.937)\end{array}$ \\
\hline Fair or poor on both jobs & --- & $\begin{array}{l}-0.185 \\
(1.135)\end{array}$ & $\begin{array}{l}-0.179 \\
(1.139)\end{array}$ & $\begin{array}{l}-0.235 \\
(1.139)\end{array}$ \\
\hline [Ref: Excellent, very good, good on both jobs] & --- & --- & --- & --- \\
\hline
\end{tabular}


Table 12 (continued).

\begin{tabular}{|c|c|c|c|c|}
\hline & (1) & (2) & (3) & (4) \\
\hline \multicolumn{5}{|l|}{ Region } \\
\hline Northeast & --- & $\begin{array}{l}-0.524 \\
(0.783)\end{array}$ & $\begin{array}{l}-0.522 \\
(0.783)\end{array}$ & $\begin{array}{l}-0.497 \\
(0.783)\end{array}$ \\
\hline [Reference: Midwest] & --- & --- & --- & --- \\
\hline South & --- & $\begin{array}{l}-0.446 \\
(0.703)\end{array}$ & $\begin{array}{l}-0.419 \\
(0.704)\end{array}$ & $\begin{array}{l}-0.397 \\
(0.704)\end{array}$ \\
\hline West & --- & $\begin{array}{l}-1.062 \\
(0.758)\end{array}$ & $\begin{array}{l}-1.057 \\
(0.759)\end{array}$ & $\begin{array}{l}-1.065 \\
(0.759)\end{array}$ \\
\hline Union member & --- & $\begin{array}{l}0.275 \\
(0.775)\end{array}$ & $\begin{array}{l}0.257 \\
(0.776)\end{array}$ & $\begin{array}{l}0.149 \\
(0.779)\end{array}$ \\
\hline Job tenure (in months), old job & --- & $\begin{array}{l}-0.0137^{* *} \\
(0.004)\end{array}$ & $\begin{array}{l}-0.0138^{* *} \\
(0.004)\end{array}$ & $\begin{array}{l}-0.0138^{* *} \\
(0.004)\end{array}$ \\
\hline Self employed on new job & --- & $\begin{array}{l}1.238 \\
(1.436)\end{array}$ & $\begin{array}{l}1.201 \\
(1.437)\end{array}$ & $\begin{array}{l}1.506 \\
(1.446)\end{array}$ \\
\hline \multicolumn{5}{|l|}{ Employer size (no. of employees) } \\
\hline Moved to larger employer than old job & --- & $\begin{array}{l}0.581 \\
(0.677)\end{array}$ & $\begin{array}{l}0.588 \\
(0.677)\end{array}$ & $\begin{array}{l}0.642 \\
(0.679)\end{array}$ \\
\hline Moved to smaller employer & --- & $\begin{array}{l}-1.103^{*} \\
(0.651)\end{array}$ & $\begin{array}{l}-1.118^{*} \\
(0.652)\end{array}$ & $\begin{array}{l}-1.037 \\
(0.653)\end{array}$ \\
\hline [Reference: New employer is same size] & --- & --- & --- & --- \\
\hline \multicolumn{5}{|l|}{ Part-time status } \\
\hline Moved from full-time to part-time & --- & $\begin{array}{l}-6.712 * * \\
(2.093)\end{array}$ & $\begin{array}{l}-6.702 * * \\
(2.096)\end{array}$ & $\begin{array}{l}-6.795 * * \\
(2.099)\end{array}$ \\
\hline Moved from part-time to full-time & --- & $\begin{array}{l}-1.797 \\
(1.762)\end{array}$ & $\begin{array}{l}-1.803 \\
(1.763)\end{array}$ & $\begin{array}{l}-1.882 \\
(1.764)\end{array}$ \\
\hline Part-time on both jobs & --- & $\begin{array}{l}-4.373 * * \\
(0.829)\end{array}$ & $\begin{array}{l}-4.378 * * \\
(0.830)\end{array}$ & $\begin{array}{l}-4.418 * * \\
(0.832)\end{array}$ \\
\hline \multicolumn{5}{|l|}{ [Reference: Full-time on both jobs] } \\
\hline Log of household wealth & --- & --- & $\begin{array}{l}0.121 \\
(0.161)\end{array}$ & $\begin{array}{l}0.128 \\
(0.161)\end{array}$ \\
\hline Indicator for negative wealth & --- & --- & $\begin{array}{l}1.779 \\
(1.810)\end{array}$ & $\begin{array}{l}1.856 \\
(1.810)\end{array}$ \\
\hline Work in same occupation, both jobs & --- & --- & --- & $\begin{array}{c}-0.0334 \\
(0.546)\end{array}$ \\
\hline Work in same industry, both jobs & --- & --- & --- & $\begin{array}{l}0.995^{*} \\
(0.546)\end{array}$ \\
\hline
\end{tabular}

(continued) 
Table 12 (continued).

\begin{tabular}{|c|c|c|c|c|}
\hline & (1) & (2) & (3) & (4) \\
\hline \multicolumn{5}{|l|}{ Year } \\
\hline [Reference: 1996] & --- & --- & --- & --- \\
\hline 1997 & --- & $\begin{array}{l}-0.465 \\
(1.050)\end{array}$ & $\begin{array}{l}-0.465 \\
(1.050)\end{array}$ & $\begin{array}{l}-0.399 \\
(1.051)\end{array}$ \\
\hline 1998 & --- & $\begin{array}{l}2.178^{*} \\
(1.226)\end{array}$ & $\begin{array}{l}2.186^{*} \\
(1.226)\end{array}$ & $\begin{array}{l}2.219^{*} \\
(1.226)\end{array}$ \\
\hline 1999 & --- & $\begin{array}{l}1.141 \\
(1.497)\end{array}$ & $\begin{array}{l}1.139 \\
(1.497)\end{array}$ & $\begin{array}{l}1.229 \\
(1.497)\end{array}$ \\
\hline 2000 & --- & $\begin{array}{l}-4.687 \\
(4.651)\end{array}$ & $\begin{array}{l}-4.775 \\
(4.652)\end{array}$ & $\begin{array}{l}-4.681 \\
(4.653)\end{array}$ \\
\hline 2001 & --- & $\begin{array}{l}-0.664 \\
(1.022)\end{array}$ & $\begin{array}{l}-0.718 \\
(1.024)\end{array}$ & $\begin{array}{l}-0.663 \\
(1.025)\end{array}$ \\
\hline 2002 & --- & $\begin{array}{l}-1.642 \\
(1.048)\end{array}$ & $\begin{array}{l}-1.632 \\
(1.049)\end{array}$ & $\begin{array}{l}-1.610 \\
(1.050)\end{array}$ \\
\hline 2003 & --- & $\begin{array}{l}-2.105^{*} \\
(1.189)\end{array}$ & $\begin{array}{l}-2.127^{*} \\
(1.190)\end{array}$ & $\begin{array}{l}-2.023 * \\
(1.191)\end{array}$ \\
\hline 2004 & --- & $\begin{array}{l}-0.211 \\
(1.028)\end{array}$ & $\begin{array}{l}-0.253 \\
(1.029)\end{array}$ & $\begin{array}{l}-0.179 \\
(1.030)\end{array}$ \\
\hline 2005 & --- & $\begin{array}{l}-1.415 \\
(1.093)\end{array}$ & $\begin{array}{l}-1.450 \\
(1.094)\end{array}$ & $\begin{array}{l}-1.413 \\
(1.094)\end{array}$ \\
\hline 2006 & --- & $\begin{array}{l}-1.623 \\
(1.282)\end{array}$ & $\begin{array}{l}-1.654 \\
(1.283)\end{array}$ & $\begin{array}{l}-1.657 \\
(1.283)\end{array}$ \\
\hline 2007 & --- & $\begin{array}{l}1.811 \\
(2.004)\end{array}$ & $\begin{array}{l}1.789 \\
(2.004)\end{array}$ & $\begin{array}{l}1.787 \\
(2.005)\end{array}$ \\
\hline Constant & $\begin{array}{l}-0.0592 \\
(0.511)\end{array}$ & $\begin{array}{l}5.124 * * \\
(1.440)\end{array}$ & $\begin{array}{l}3.774 * \\
(2.202)\end{array}$ & $\begin{array}{l}3.164 \\
(2.229)\end{array}$ \\
\hline $\mathrm{N}$ & 2641 & 2641 & 2641 & 2641 \\
\hline R-squared & 0.015 & 0.052 & 0.052 & 0.054 \\
\hline Mean of dependent variable & -0.860 & -0.860 & -0.860 & -0.860 \\
\hline
\end{tabular}

Source: Authors' estimates from the 1996, 2001, and 2004 SIPP panels, spanning the years 1996 to 2007.

Note: Standard errors are in parenthesis. All financial amounts are expressed in constant 2009 dollars. The sample is restricted to wage and salary workers age 18 and older who left their jobs because of layoff, slack work, or employer bankruptcy, or because the employer sold the business, and became reemployed during the observation period. Unless noted, variables are measured at the beginning of the new job.

$* * p<.05 ; * .10>p>.05$ 
Table 13. OLS Regressions of Change in Hourly Earnings for Displaced Female Wage and Salary Workers who Become Reemployed

\begin{tabular}{|c|c|c|c|c|}
\hline & (1) & (2) & (3) & (4) \\
\hline \multicolumn{5}{|l|}{ Age } \\
\hline $18-24$ & $\begin{array}{l}3.731 * * \\
(0.784)\end{array}$ & $\begin{array}{l}2.453^{* *} \\
(0.842)\end{array}$ & $\begin{array}{l}2.563 * * \\
(0.846)\end{array}$ & $\begin{array}{l}2.648 * * \\
(0.849)\end{array}$ \\
\hline [Reference: 25-34] & --- & --- & --- & --- \\
\hline $35-49$ & $\begin{array}{l}0.193 \\
(0.608)\end{array}$ & $\begin{array}{l}0.162 \\
(0.632)\end{array}$ & $\begin{array}{l}0.299 \\
(0.640)\end{array}$ & $\begin{array}{l}0.240 \\
(0.640)\end{array}$ \\
\hline $50-61$ & $\begin{array}{l}-0.433 \\
(0.757)\end{array}$ & $\begin{array}{l}-0.119 \\
(0.819)\end{array}$ & $\begin{array}{l}0.114 \\
(0.834)\end{array}$ & $\begin{array}{l}0.0522 \\
(0.835)\end{array}$ \\
\hline 62 and older & $\begin{array}{l}-0.499 \\
(1.434)\end{array}$ & $\begin{array}{l}-1.552 \\
(1.569)\end{array}$ & $\begin{array}{l}-1.094 \\
(1.599)\end{array}$ & $\begin{array}{l}-1.223 \\
(1.600)\end{array}$ \\
\hline \multicolumn{5}{|l|}{ Race and ethnicity } \\
\hline African American & --- & $\begin{array}{l}-0.311 \\
(0.701)\end{array}$ & $\begin{array}{l}-0.479 \\
(0.716)\end{array}$ & $\begin{array}{l}-0.512 \\
(0.716)\end{array}$ \\
\hline Hispanic & --- & $\begin{array}{l}0.00893 \\
(0.750)\end{array}$ & $\begin{array}{l}-0.104 \\
(0.755)\end{array}$ & $\begin{array}{l}-0.165 \\
(0.756)\end{array}$ \\
\hline [Reference: Non-Hispanic white] & --- & --- & --- & --- \\
\hline Other & --- & $\begin{array}{l}0.508 \\
(1.083)\end{array}$ & $\begin{array}{l}0.443 \\
(1.084)\end{array}$ & $\begin{array}{l}0.388 \\
(1.085)\end{array}$ \\
\hline \multicolumn{5}{|l|}{ Education } \\
\hline Not high school graduate & --- & $\begin{array}{l}1.171 \\
(0.772)\end{array}$ & $\begin{array}{l}1.065 \\
(0.775)\end{array}$ & $\begin{array}{l}0.981 \\
(0.778)\end{array}$ \\
\hline [Reference: High school graduate] & --- & --- & --- & --- \\
\hline Some college & --- & $\begin{array}{l}0.130 \\
(0.577)\end{array}$ & $\begin{array}{l}0.178 \\
(0.578)\end{array}$ & $\begin{array}{l}0.165 \\
(0.578)\end{array}$ \\
\hline Four or more years of college & --- & $\begin{array}{l}-0.417 \\
(0.743)\end{array}$ & $\begin{array}{l}-0.217 \\
(0.755)\end{array}$ & $\begin{array}{l}-0.258 \\
(0.755)\end{array}$ \\
\hline \multicolumn{5}{|l|}{ Marital status } \\
\hline [Reference: Married] & --- & --- & --- & --- \\
\hline Divorced or separated & --- & $\begin{array}{l}-0.454 \\
(1.059)\end{array}$ & $\begin{array}{l}-0.508 \\
(1.061)\end{array}$ & $\begin{array}{l}-0.504 \\
(1.061)\end{array}$ \\
\hline Widowed & --- & $\begin{array}{l}-0.264 \\
(1.709)\end{array}$ & $\begin{array}{l}-0.263 \\
(1.709)\end{array}$ & $\begin{array}{l}-0.297 \\
(1.709)\end{array}$ \\
\hline Never married & --- & $\begin{array}{l}-1.069 \\
(1.098)\end{array}$ & $\begin{array}{l}-1.028 \\
(1.100)\end{array}$ & $\begin{array}{l}-1.116 \\
(1.101)\end{array}$ \\
\hline Spouse employed & --- & $\begin{array}{l}-0.365 \\
(1.001)\end{array}$ & $\begin{array}{l}-0.257 \\
(1.004)\end{array}$ & $\begin{array}{l}-0.303 \\
(1.004)\end{array}$ \\
\hline \multicolumn{5}{|l|}{ Health Status } \\
\hline Fair or poor on new job, better on old job & --- & $\begin{array}{l}-0.447 \\
(1.693)\end{array}$ & $\begin{array}{l}-0.557 \\
(1.694)\end{array}$ & $\begin{array}{l}-0.498 \\
(1.694)\end{array}$ \\
\hline Excellent, very good, or good on new job, worse on old job & --- & $\begin{array}{l}-2.157 \\
(1.553)\end{array}$ & $\begin{array}{l}-2.211 \\
(1.554)\end{array}$ & $\begin{array}{l}-2.232 \\
(1.553)\end{array}$ \\
\hline Fair or poor on both jobs & --- & $\begin{array}{l}0.155 \\
(0.964)\end{array}$ & $\begin{array}{l}0.0643 \\
(0.967)\end{array}$ & $\begin{array}{l}0.0622 \\
(0.967)\end{array}$ \\
\hline [Ref: Excellent, very good, good on both jobs] & --- & --- & --- & --- \\
\hline
\end{tabular}


Table 13 (continued).

\begin{tabular}{|c|c|c|c|c|}
\hline & (1) & $(2)$ & (3) & (4) \\
\hline \multicolumn{5}{|l|}{ Region } \\
\hline Northeast & --- & $\begin{array}{l}0.263 \\
(0.755)\end{array}$ & $\begin{array}{l}0.320 \\
(0.758)\end{array}$ & $\begin{array}{l}0.264 \\
(0.759)\end{array}$ \\
\hline [Reference: Midwest] & --- & --- & --- & --- \\
\hline South & --- & $\begin{array}{l}0.0662 \\
(0.669)\end{array}$ & $\begin{array}{l}0.0505 \\
(0.669)\end{array}$ & $\begin{array}{l}0.0497 \\
(0.669)\end{array}$ \\
\hline West & --- & $\begin{array}{l}0.163 \\
(0.745)\end{array}$ & $\begin{array}{l}0.201 \\
(0.746)\end{array}$ & $\begin{array}{l}0.187 \\
(0.746)\end{array}$ \\
\hline Union member & --- & $\begin{array}{l}-0.315 \\
(1.050)\end{array}$ & $\begin{array}{l}-0.351 \\
(1.050)\end{array}$ & $\begin{array}{l}-0.453 \\
(1.052)\end{array}$ \\
\hline Job tenure (in months), old job & --- & $\begin{array}{l}-0.0104 * * \\
(0.004)\end{array}$ & $\begin{array}{l}-0.00982 * * \\
(0.004)\end{array}$ & $\begin{array}{l}-0.00979 * * \\
(0.004)\end{array}$ \\
\hline Self employed on new job & --- & $\begin{array}{l}0.852 \\
(1.576)\end{array}$ & $\begin{array}{l}0.904 \\
(1.577)\end{array}$ & $\begin{array}{l}1.214 \\
(1.589)\end{array}$ \\
\hline \multicolumn{5}{|l|}{ Employer size (no. of employees) } \\
\hline Moved to larger employer than old job & --- & $\begin{array}{l}1.133^{*} \\
(0.635)\end{array}$ & $\begin{array}{l}1.099 * \\
(0.635)\end{array}$ & $\begin{array}{l}1.145^{*} \\
(0.636)\end{array}$ \\
\hline Moved to smaller employer & --- & $\begin{array}{l}-1.454 * * \\
(0.610)\end{array}$ & $\begin{array}{l}-1.467 * * \\
(0.610)\end{array}$ & $\begin{array}{l}-1.381 * * \\
(0.612)\end{array}$ \\
\hline [Reference: New employer is same size] & --- & --- & --- & --- \\
\hline \multicolumn{5}{|l|}{ Part-time status } \\
\hline Moved from full-time to part-time & --- & $\begin{array}{l}-5.059^{* *} \\
(1.644)\end{array}$ & $\begin{array}{l}-5.139 * * \\
(1.644)\end{array}$ & $\begin{array}{l}-5.138^{* *} \\
(1.644)\end{array}$ \\
\hline Moved from part-time to full-time & --- & $\begin{array}{l}-0.567 \\
(1.306)\end{array}$ & $\begin{array}{l}-0.659 \\
(1.307)\end{array}$ & $\begin{array}{l}-0.636 \\
(1.307)\end{array}$ \\
\hline Part-time on both jobs & --- & $\begin{array}{l}-4.343^{* *} \\
(0.573)\end{array}$ & $\begin{array}{l}-4.375 * * \\
(0.575)\end{array}$ & $\begin{array}{l}-4.294 * * \\
(0.577)\end{array}$ \\
\hline [Reference: Full-time on both jobs] & --- & --- & --- & --- \\
\hline Log of household wealth & --- & --- & $\begin{array}{l}-0.236 \\
(0.156)\end{array}$ & $\begin{array}{l}-0.233 \\
(0.156)\end{array}$ \\
\hline Indicator for negative wealth & --- & --- & $\begin{array}{l}-2.261 \\
(1.724)\end{array}$ & $\begin{array}{l}-2.212 \\
(1.724)\end{array}$ \\
\hline Work in same occupation, both jobs & --- & --- & --- & $\begin{array}{l}0.417 \\
(0.502)\end{array}$ \\
\hline Work in same industry, both jobs & --- & --- & --- & $\begin{array}{l}0.614 \\
(0.506)\end{array}$ \\
\hline
\end{tabular}

(continued) 
Table 13 (continued).

\begin{tabular}{|c|c|c|c|c|}
\hline & (1) & (2) & (3) & (4) \\
\hline \multicolumn{5}{|l|}{ Year } \\
\hline [Reference: 1996] & --- & --- & --- & --- \\
\hline 1997 & --- & $\begin{array}{l}-0.189 \\
(1.001)\end{array}$ & $\begin{array}{l}-0.216 \\
(1.001)\end{array}$ & $\begin{array}{l}-0.171 \\
(1.002)\end{array}$ \\
\hline 1998 & --- & $\begin{array}{l}0.345 \\
(1.164)\end{array}$ & $\begin{array}{l}0.347 \\
(1.164)\end{array}$ & $\begin{array}{l}0.418 \\
(1.165)\end{array}$ \\
\hline 1999 & --- & $\begin{array}{l}0.918 \\
(1.255)\end{array}$ & $\begin{array}{l}0.922 \\
(1.254)\end{array}$ & $\begin{array}{l}1.032 \\
(1.257)\end{array}$ \\
\hline 2000 & --- & $\begin{array}{l}-7.133 \\
(4.933)\end{array}$ & $\begin{array}{l}-7.087 \\
(4.933)\end{array}$ & $\begin{array}{l}-6.758 \\
(4.936)\end{array}$ \\
\hline 2001 & --- & $\begin{array}{l}0.605 \\
(1.035)\end{array}$ & $\begin{array}{l}0.568 \\
(1.035)\end{array}$ & $\begin{array}{l}0.626 \\
(1.035)\end{array}$ \\
\hline 2002 & --- & $\begin{array}{l}-0.821 \\
(1.024)\end{array}$ & $\begin{array}{l}-0.831 \\
(1.026)\end{array}$ & $\begin{array}{l}-0.695 \\
(1.030)\end{array}$ \\
\hline 2003 & --- & $\begin{array}{l}-0.820 \\
(1.161)\end{array}$ & $\begin{array}{l}-0.783 \\
(1.161)\end{array}$ & $\begin{array}{l}-0.726 \\
(1.163)\end{array}$ \\
\hline 2004 & --- & $\begin{array}{l}0.810 \\
(1.051)\end{array}$ & $\begin{array}{l}0.770 \\
(1.052)\end{array}$ & $\begin{array}{l}0.841 \\
(1.053)\end{array}$ \\
\hline 2005 & --- & $\begin{array}{l}-0.668 \\
(1.035)\end{array}$ & $\begin{array}{l}-0.683 \\
(1.035)\end{array}$ & $\begin{array}{l}-0.562 \\
(1.038)\end{array}$ \\
\hline 2006 & --- & $\begin{array}{l}-1.284 \\
(1.221)\end{array}$ & $\begin{array}{l}-1.281 \\
(1.220)\end{array}$ & $\begin{array}{l}-1.208 \\
(1.221)\end{array}$ \\
\hline 2007 & --- & $\begin{array}{l}-0.927 \\
(1.835)\end{array}$ & $\begin{array}{l}-0.932 \\
(1.835)\end{array}$ & $\begin{array}{l}-1.011 \\
(1.836)\end{array}$ \\
\hline Constant & $\begin{array}{l}-1.674 * * \\
(0.473)\end{array}$ & $\begin{array}{l}2.719^{*} \\
(1.463)\end{array}$ & $\begin{array}{l}5.055^{* *} \\
(2.150)\end{array}$ & $\begin{array}{l}4.453 * * \\
(2.178)\end{array}$ \\
\hline $\mathrm{N}$ & 2093 & 2093 & 2093 & 2093 \\
\hline R-squared & 0.015 & 0.069 & 0.070 & 0.071 \\
\hline Mean of dependent variable & -1.132 & -1.132 & -1.132 & -1.132 \\
\hline
\end{tabular}

Source: Authors' estimates from the 1996, 2001, and 2004 SIPP panels, spanning the years 1996 to 2007.

Note: Standard errors are in parenthesis. All financial amounts are expressed in constant 2009 dollars. The sample is restricted to wage and salary workers age 18 and older who left their jobs because of layoff, slack work, or employer bankruptcy, or because the employer sold the business, and became reemployed during the observation period. Unless noted, variables are measured at the beginning of the new job.

$* * p<.05 ; * .10>p>.05$ 
Table 14. Job Search Activities in Past Four Weeks by Unemployed Workers, March, April, May, and June 2010

\begin{tabular}{|c|c|c|c|c|c|c|c|c|c|c|c|c|}
\hline & \multicolumn{10}{|c|}{ Percentage of Unemployed Workers Engaged in Each Activity } & \multirow[b]{2}{*}{$\begin{array}{c}\text { Mean } \\
\text { number of } \\
\text { search } \\
\text { methods } \\
\end{array}$} & \multirow[b]{2}{*}{$\begin{array}{c}\text { No. of } \\
\text { obs }\end{array}$} \\
\hline & $\begin{array}{c}\begin{array}{c}\text { Contacted } \\
\text { employer } \\
\text { directly/ } \\
\text { Interviewed/ } \\
\text { Sent resume or } \\
\text { application }\end{array} \\
\end{array}$ & $\begin{array}{c}\begin{array}{c}\text { Contacted } \\
\text { public } \\
\text { employment } \\
\text { agency }\end{array} \\
\end{array}$ & $\begin{array}{c}\begin{array}{c}\text { Contacted } \\
\text { private } \\
\text { employment } \\
\text { agency }\end{array} \\
\end{array}$ & 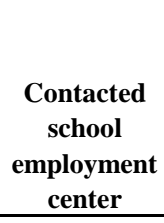 & $\begin{array}{c}\text { Checked } \\
\text { professional/ } \\
\text { union } \\
\text { registers } \\
\end{array}$ & $\begin{array}{c}\text { Contacted } \\
\text { friends or } \\
\text { relatives } \\
\end{array}$ & $\begin{array}{c}\text { Placed or } \\
\text { answered } \\
\text { ads } \\
\end{array}$ & $\begin{array}{c}\text { Looked at } \\
\text { ads }\end{array}$ & $\begin{array}{c}\text { Attended } \\
\text { job } \\
\text { training } \\
\end{array}$ & Other & & \\
\hline All & 77.1 & 19.6 & 7.7 & 3.2 & 3.3 & 27.8 & 16.3 & 29.2 & 1.3 & 7.4 & 1.94 & 17,750 \\
\hline \multicolumn{13}{|l|}{ Age } \\
\hline $18-24$ & 84.0 & 15.7 & 5.8 & 3.8 & 1.6 & 23.6 & 15.0 & 27.5 & 0.7 & 6.7 & 1.86 & 4,667 \\
\hline $25-34$ & 78.9 & 20.9 & 7.8 & 3.5 & 3.5 & 27.7 & 15.3 & 29.6 & 1.8 & 6.9 & 1.97 & 4,358 \\
\hline $35-49$ & 74.3 & 22.6 & 8.7 & 2.9 & 3.8 & 30.3 & 17.1 & 29.8 & 1.6 & 8.4 & 2.00 & 4,553 \\
\hline $50-61$ & 71.6 & 20.8 & 9.2 & 2.8 & 5.4 & 30.8 & 20.0 & 31.2 & 1.4 & 7.8 & 2.02 & 3,153 \\
\hline $62+$ & 62.2 & 15.5 & 6.6 & 1.7 & 2.5 & 30.0 & 12.9 & 27.7 & 1.2 & 7.8 & 1.67 & 1,019 \\
\hline \multicolumn{13}{|l|}{ Sex } \\
\hline Male & 75.4 & 20.0 & 7.7 & 3.0 & 3.8 & 29.7 & 15.8 & 28.2 & 1.3 & 7.3 & 1.92 & 9,875 \\
\hline Female & 79.3 & 19.0 & 7.6 & 3.5 & 2.7 & 25.4 & 17.1 & 30.6 & 1.4 & 7.6 & 1.96 & 7,875 \\
\hline \multicolumn{13}{|l|}{ Race and ethnicity } \\
\hline African American & 80.8 & 23.5 & 8.8 & 4.5 & 2.9 & 27.2 & 14.9 & 28.3 & 2.2 & 7.2 & 2.03 & 2,931 \\
\hline Hispanic & 75.4 & 19.9 & 8.2 & 2.7 & 2.2 & 31.5 & 12.3 & 24.7 & 1.3 & 6.1 & 1.85 & 2,903 \\
\hline Non-Hispanic white & 76.4 & 18.3 & 7.0 & 2.8 & 3.8 & 26.5 & 18.1 & 30.8 & 1.1 & 7.8 & 1.93 & 10,508 \\
\hline Other & 80.6 & 22.8 & 3.1 & 1.4 & 2.7 & 18.8 & 21.0 & 28.5 & 1.1 & 8.7 & 1.90 & 305 \\
\hline \multicolumn{13}{|l|}{ Education } \\
\hline Not high school grad & 76.6 & 18.1 & 6.3 & 2.1 & 1.9 & 28.7 & 12.4 & 25.6 & 1.0 & 5.7 & 1.79 & 3,269 \\
\hline High school grad & 76.2 & 21.2 & 7.6 & 2.2 & 2.9 & 27.9 & 16.5 & 30.2 & 1.0 & 6.1 & 1.93 & 6,727 \\
\hline Some College & 78.6 & 19.6 & 7.6 & 4.0 & 3.1 & 25.9 & 16.8 & 30.6 & 1.8 & 8.5 & 1.98 & 4,997 \\
\hline Four or more yrs of college & 77.0 & 17.3 & 9.7 & 5.7 & 6.4 & 29.9 & 19.9 & 29.1 & 1.6 & 10.8 & 2.09 & 2,757 \\
\hline
\end{tabular}

Source: Authors' computations from the March, April, May, and June 2010 Current Population Survey. 


\section{RECENT WORKING PAPERS FROM THE CENTER FOR RETIREMENT RESEARCH AT BOSTON COLLEGE}

The Earnings and Social Security Contributions of Documented and Undocumented Mexican Immigrants

Gary Burtless and Audrey Singer, January 2011

How Important Are Intergenerational Transfers for Baby Boomers?

Alicia H. Munnell, Anthony Webb, Zhenya Karamcheva, and Andrew Eschtruth, January 2011

Effect of Informal Care on Work, Wages, and Wealth

Courtney Harold Van Houtven, Norma B. Coe, and Meghan Skira, December 2010

Recessions, Wealth Destruction, and the Timing of Retirement

Barry P. Bosworth and Gary Burtless, December 2010

Measuring the Spillover to Disability Insurance Due to the Rise in the Full Retirement Age Norma B. Coe and Kelly Haverstick, December 2010

Is the Reduction in Older Workers' Job Tenure a Cause for Concern?

Steven A. Sass and Anthony Webb, December 2010

Accounting for Disability Insurance in the Dynamic Relationship Between Disability Onset and Earnings

Perry Singleton, November 2010

The Treatment of Married Women by the Social Security Retirement Program Andrew G. Biggs, Gayle L. Reznik, and Nada O. Eissa, November 2010

What is the Impact of Foreclosures on Retirement Security?

Irena Dushi, Leora Friedberg, and Anthony Webb, November 2010

Children and Household Utility: Evidence from Kids Flying the Coop

Norma B. Coe and Anthony Webb, November 2010

Overview of the CRR 2009 Retirement Survey

Alicia H. Munnell, Norma B. Coe, Kelly Haverstick, and Steven A. Sass, October 2010

State Wage-Payment Laws, the Pension Protection Act of 2006, and 401(k) Saving Behavior

Gary V. Englehardt, October 2010

Asset Cycles and the Retirement Decisions of Older Workers Jan Ondrich, October 2010

All working papers are available on the Center for Retirement Research website (http://crr.bc.edu) and can be requested by e-mail (crr@bc.edu) or phone (617-552-1762). 